\title{
Environmental Factors that Impact the Workplace Participation of Transition-Aged Young Adults with Brain-Based Disabilities: A Scoping Review
}

\author{
Saeideh Shahin $1,2, *\left(\mathbb{D}\right.$, Meaghan Reitzel ${ }^{3,4}$, Briano Di Rezze ${ }^{3,4}$, Sara Ahmed ${ }^{1,2}$ and \\ Dana Anaby 1,2,4 (1) \\ 1 School of Physical and Occupational Therapy, McGill University; Montreal, QC H3J1Y5, Canada; \\ sara.ahmed@mcgill.ca (S.A.); dana.anaby@mcgill.ca (D.A.) \\ 2 Centre de Recherche Interdisciplinaire en Réadaptation de Montréal Métropolitain (CRIR); Montreal, \\ QC H3S1M9, Canada \\ 3 School of Rehabilitation Science, McMaster University; Hamilton, ON L8S1C7, Canada; \\ reitzelm@mcmaster.ca (M.R.); direzzbm@mcmaster.ca (B.D.R.) \\ 4 CanChild Center for Childhood Disability Research; Hamilton, ON L8S1C7, Canada \\ * Correspondence: Saeideh.shahinvarnousfaderany@mail.mcgill.ca
}

Received: 24 February 2020; Accepted: 29 March 2020; Published: 31 March 2020

\begin{abstract}
Workplace participation of individuals with disabilities continues to be a challenge. The International Classification of Functioning, Disability and Health (ICF) places importance on the environment in explaining participation in different life domains, including work. A scoping review was conducted to investigate environmental facilitators and barriers relevant to workplace participation for transition-aged young adults aged 18-35 with brain-based disabilities. Studies published between 1995 and 2018 were screened by two reviewers. Findings were categorized into the ICF's environmental domains: Products and technology/Natural environment and human-made changes to environment, Support and relationships, Attitudes, and Services, systems and policies. Out of 11,515 articles screened, 31 were retained. All environmental domains of the ICF influenced workplace participation. The majority of the studies (77\%) highlighted factors in the Services, systems and policies domain such as inclusive and flexible systems, and well-defined policies exercised at the organizational level. Social support mainly from family, friends, employers and colleagues was reported as a facilitator (68\%), followed by physical accessibility and finally, the availability of assistive technology (55\%). Attitudes of colleagues and employers were mostly seen as a barrier to workplace participation (48\%). Findings can inform the development of guidelines and processes for implementing and reinforcing policies, regulations and support at the organization level.
\end{abstract}

Keywords: young adult; employment; workplace; labor force; environmental impacts; social environment

\section{Introduction}

Participation, defined as "involvement in a life situation" by the International Classification of Functioning, Disability and Health (ICF) [1], is one of the main rehabilitation goals among people with disabilities [2]. Participation in work is particularly important for transition-aged young adults living with a disability which involves transition to many new adulthood roles; however, this group often experiences increased participation limitations over time, in this pertinent life area [3].

Generally, employment is associated with improved physical, psychological and social well-being [4]. Having work experience is important for young adults, especially for those with disabilities, as it increases the likelihood of attaining postsecondary employment later in adulthood [5]. Despite its known benefits, young adults with disabilities in North America [6] and around the 
world have the lowest employment rates, between $30 \%-53 \%$ [7]. This group also experiences higher rates of poverty when compared to those without disabilities [8]. Focusing on this vulnerable transition-aged group is critical as it involves transitioning to adulthood roles and requires support to ensure successful experiences in their early stages of employment. Such support is important since open and competitive employment settings do not always have the knowledge and resources to make appropriate accommodations [9].

Environmental factors, referring to the physical, social, attitudinal and institutional facets of the environment, are known to affect participation outcomes [10]. These factors can either act as facilitators and enhance one's functioning and participation, and/or serve as barriers impeding one's engagement in meaningful activities [1]. Hence, the environment may explain some of the discrepancies in employment rates among young adults with disabilities [11,12]. Research suggests that the environment can serve as a promising target for interventions to improve participation. Additionally, in many cases, change at the level of the environment is a more practical target rather than at the level of the individual [10]. Understanding the challenges that the environment poses for participation in the workplace among this population can inform such interventions. Recent knowledge syntheses have illustrated the impact of environmental modifications on workplace participation among adults with autism spectrum disorder (ASD) [13] and workplace culture on the participation of people with intellectual disability (ID) [14]. However, to date, no scoping review has been completed to comprehensively synthesize the knowledge-base related to the environmental effects on the workplace participation among the understudied population of transition-aged young adults with various brain-based disabilities [15].

This scoping review aimed to identify and synthesize the existing evidence on the impact of environment on participation in mainstream inclusive work settings among transition-aged young adults with brain-based disabilities. Brain-based disabilities refer to any neurologically based congenital or acquired conditions, as well as neurologically chronic conditions (e.g., cerebral palsy, brain- and spinal-related injuries) including sensory disorders. Such an initiative will also reveal current gaps in knowledge within the field of employment in brain-based disability, informing future research.

\section{Materials and Methods}

A scoping review methodology was applied, allowing us to map and broadly cover the breadth of current knowledge regarding the environmental factors that impact employment participation of transition-aged individuals [16]. The 5-stage method for scoping reviews by Arksey and O'Mally [16] and advanced by O'Brien, Colquhoun and Levac [17] was used.

\subsection{Identifying the Research Question}

Typical to scoping reviews, a broad question was identified as follows: What is known about the impact of the environment on the participation in the work setting among transition-aged individuals with brain-based disabilities?

\subsection{Identifying Relevant Studies}

A systemic search of studies published between 1995 and June 2018 was conducted. Five relevant databases covering a range of research areas including health, social and rehabilitation sciences were consulted: OVID MEDLINE, EMBASE, PsycINFO, PubMed and CINHAL. The input of an expert librarian ensured that all relevant publications were included. The following search terms (see Table 1) were utilized to capture the multi-faceted aspects of the environment combined with OR: physical environment, social environment, cultural environment, institutional environment, built environment, attitudes, workplace, accessibility, services, policy, social support, and relationships. Comprehensive keywords were used to capture the concept of 'work participation', using terms representing 'participation' (e.g., engagement, involvement) combined with terms illustrating 'employment' (e.g., job, productivity). These three categories of terms were combined with the term 'brain-based disability' and related conditions (for further details see Table 1) using AND. Both Medical Subject Headings 
$(\mathrm{MeSH})$ and keywords were used. Final searches resulted in 14119 articles, which were organized via EndNote reference manager. The removal of duplicates resulted in 11,515 articles.

Table 1. Search terms used.

\begin{tabular}{|c|c|c|c|}
\hline Database & $\begin{array}{c}\text { Environment } \\
\text { [Combined Using OR] }\end{array}$ & $\begin{array}{l}\text { Work Participation } \\
\text { [Combined Using OR] }\end{array}$ & Disability [Combined Using OR] \\
\hline $\begin{array}{l}\text { 1. OVID } \\
\text { 2. MEDLINE } \\
\text { 3. EMBASE } \\
\text { 4. PsycINFO } \\
\text { 5. PubMed } \\
\text { 6. CINHAL }\end{array}$ & $\begin{array}{l}\text { Physical environment } \\
\text { Social environment } \\
\text { Cultural environment } \\
\text { Institutional } \\
\text { environment } \\
\text { Social support } \\
\text { Relationship } \\
\text { Attitude } \\
\text { Accessibility } \\
\text { Architectural } \\
\text { accessibility } \\
\text { Service } \\
\text { Policy } \\
\text { Built environment } \\
\text { Environmental design } \\
\text { Organizational climate }\end{array}$ & $\begin{array}{l}\text { Employment } \\
\text { Employment status } \\
\text { Participation } \\
\text { Involvement } \\
\text { Engagement } \\
\text { Workplace } \\
\text { Work } \\
\text { Job } \\
\text { Vocational } \\
\text { Part time job } \\
\text { Productivity } \\
\text { Volunteer } \\
\text { Part-time work } \\
\text { Labor market }\end{array}$ & $\begin{array}{l}\text { Brain-based disabilities } \\
\text { Cerebral palsy } \\
\text { Brain hemorrhage } \\
\text { Traumatic brain injury } \\
\text { Cognitive impairment } \\
\text { Epilepsy, post-traumatic epilepsy } \\
\text { Hydrocephalus } \\
\text { Meningitis, bacterial Meningitis, fungal } \\
\text { Meningitis, viral Meningoencephalitis } \\
\text { Child development disorders, } \\
\text { Developmental disabilities } \\
\text { Intellectual disability } \\
\text { Learning disorders } \\
\text { Motor skills disorders } \\
\text { Tic disorders } \\
\text { Global developmental delay } \\
\text { Autism spectrum disorder } \\
\text { Asperger syndrome } \\
\text { Developmental coordination disorder } \\
\text { Sensory integration disorder } \\
\text { Sensory system disorder } \\
\text { Disorder, Spina bifida } \\
\text { Acquired brain injury }\end{array}$ \\
\hline
\end{tabular}

\subsection{Study Selection}

Empirical peer-reviewed studies, regardless of their design, were included if they: (1) explored the relationship between the environment and participation in an open competitive workplace, (2) targeted transition-aged young adults between the ages of 18-35 years old (based on the mean) with acquired or congenital brain-based disabilities, and (3) were published in English. This age range was chosen as it reflects a period of transitioning to adulthood, which involves greater independence, acquiring employment, and maintaining relationships and leisure activities [18]. Full-time employment usually begins at 18 [19], and because dependency on family is prolonged within this population, this transition phase was extended to the mid-30s [20]. Articles were excluded if they had the following characteristics: (1) theoretical, conceptual or opinion papers, (2) studies whose participants' primary diagnosis was a mental health condition, (3) studies that only focused on recommendations to occupational health and safety guidelines in the workplace or included only descriptions of work hardening programs, vocational rehabilitation programs and facility-based programs, or the impact of the environment on these programs. Three researchers independently screened an initial set of 50 articles by title and abstract, attaining a 90\% agreement [21]. The remaining articles were equally distributed and screened by title/abstract, resulting in 221 studies retained for full-text screening by two researchers. Any disagreement was resolved through discussions and consultations with the senior investigator. Finally, 25\% of the included and excluded articles were randomly selected and validated by a rehabilitation specialist, independent of the study. Consensus was reached through a discussion.

\subsection{Extracting and Charting Results}

A data extraction sheet containing the reference, year and country of publication, type of study and design, study purpose, number and age of participants, diagnosis, place of employment, aspects of the environment and participation, main findings, and utilized assessment tools was created using Excel. Elo and Kyngäs' [22] coding and categorization process was used to classify data according to the five environmental domains of the ICF framework: Products \& technology (e.g., assistive devices, 
built environment), Natural environment and human-made changes to environment (e.g., geographic location, climate), Support \& relationships (e.g., including family, friends, colleagues, and healthcare professionals), Attitudes (e.g., belief, values and perceptions of others), and Systems, services \& policies (e.g., programs, regulations). This comprehensive framework was selected as it accords special attention to the role of the environment on participation [23]. The Products and technology domain was combined with the Natural environment and human-made changes to environment domain into one category as they both relate to the physical environment, resulting in four domains of the environment. Main findings categorized into the ICF environmental domains were jointly validated by two researchers followed by input from the senior researcher [24].

\subsection{Collating, Summarizing and Reporting the Results}

A descriptive summary of each article is presented with regards to the following elements (see Table 2): author, year, country, aim of the study, study design, population (number, age, diagnostic), ICF environmental domains included, and summary of the main findings. Data was described in terms of the percentage of the articles that explored specific environmental domains of the ICF. Additionally, findings were synthesized to explore the range of identified environmental barriers/facilitators that contribute to young adults' workplace participation. A table (see Table 3) summarizing findings in terms of environmental barriers and facilitators per each ICF environmental domain was also created. 
Table 2. The main findings of the individual articles $(n=31)$.

\begin{tabular}{|c|c|c|c|c|c|c|c|c|}
\hline \multirow[t]{2}{*}{$\begin{array}{l}\text { Author, Year, } \\
\text { Country }\end{array}$} & \multirow[t]{2}{*}{ Aim of the Study } & \multirow[t]{2}{*}{ Study Design } & \multirow{2}{*}{$\begin{array}{c}\text { Population } \\
\text { (Number, Age, } \\
\text { Diagnosis) }\end{array}$} & \multicolumn{4}{|c|}{ Environmental Domains } & \multirow[t]{2}{*}{ Summary of Main Findings } \\
\hline & & & & $\begin{array}{c}\text { Products \& } \\
\text { Technology \& } \\
\text { Natural } \\
\text { Environment }\end{array}$ & $\begin{array}{c}\text { Support \& } \\
\text { Relationships }\end{array}$ & Attitudes & $\begin{array}{c}\text { Services, } \\
\text { Systems \& } \\
\text { Policies }\end{array}$ & \\
\hline $\begin{array}{l}\text { Foley et al. [24] } \\
\text { Australia }\end{array}$ & $\begin{array}{l}\text { To present parental } \\
\text { descriptions of social } \\
\text { participation of young adults } \\
\text { with Down syndrome and to } \\
\text { explore the levels of social } \\
\text { participation with physical and } \\
\text { social environment. }\end{array}$ & $\begin{array}{l}\text { Quantitative- } \\
\text { Cross-sectional } \\
\quad \text { study }\end{array}$ & $\begin{array}{c}n=197 \text { parents of } \\
\text { youth } \\
\text { Youth aged } * 16-32 \\
\text { Down syndrome }\end{array}$ & $\checkmark$ & $\checkmark$ & $\checkmark$ & & $\begin{array}{l}\text { Facilitators: } \\
\text { - } \quad \text { Positive attitudes of employers and colleagues } \\
\text { Barriers: } \\
\text { - Negative attitudes of strangers } \\
\text { - } \quad \text { Lack of support from friends } \\
\text { Unavailability of jobs and public transport }\end{array}$ \\
\hline $\begin{array}{l}\text { Roessler et al. } \\
\text { [25] } \\
\text { USA }\end{array}$ & $\begin{array}{l}\text { To demonstrate the application } \\
\text { of a contextual assessment of } \\
\text { job/person compatibility in four } \\
\text { employed college graduates with } \\
\text { TBI. }\end{array}$ & $\begin{array}{l}\text { Qualitative—case } \\
\text { study }\end{array}$ & $\begin{array}{c}n=4 \\
\text { Aged 25-32 years } \\
\text { TBI }\end{array}$ & $\checkmark$ & & $\checkmark$ & $\checkmark$ & 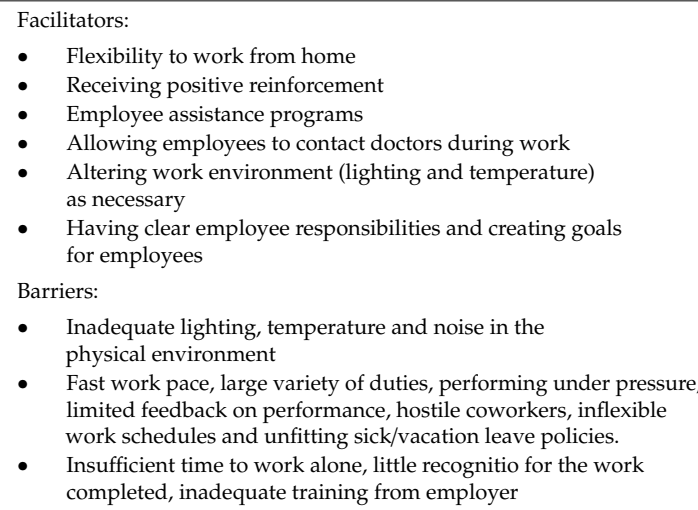 \\
\hline $\begin{array}{l}\text { Foley et al. [26] } \\
\text { Australia }\end{array}$ & $\begin{array}{l}\text { To describe the quality of life of } \\
\text { families with a young adult with } \\
\text { Down Syndrome, recently } \\
\text { transitioned from school to } \\
\text { post-school and influences of } \\
\text { post-school day occupation and } \\
\text { personal, environmental factors } \\
\text { on family quality of life. }\end{array}$ & $\begin{array}{l}\text { Quantitative- } \\
\text { cross - sectional } \\
\text { study }\end{array}$ & $\begin{array}{c}n=150 \text { families of } \\
\text { young adults with } \\
\text { Down Syndrome } \\
\text { Aged * } 16-30 \text { years } \\
(\text { mean }=22.9)\end{array}$ & $\checkmark$ & $\checkmark$ & & $\checkmark$ & $\begin{array}{l}\text { Barriers: } \\
\text { - } \quad \text { No suitable open employment jobs available } \\
\text { - } \text { shployees unable to apply for open jobs while working in } \\
\text { - } \quad \text { Unreasonabloyment } \\
\text { - } \quad \text { Lack of parental supportance } \\
\text { - } \quad \text { Oolicy and funding constraints } \\
\quad \text { with disabions prities }\end{array}$ \\
\hline
\end{tabular}


Table 2. Cont.

\begin{tabular}{|c|c|c|c|c|c|c|c|c|}
\hline \multirow{2}{*}{$\begin{array}{l}\text { Author, Year, } \\
\text { Country }\end{array}$} & \multirow[t]{2}{*}{ Aim of the Study } & \multirow[t]{2}{*}{ Study Design } & \multirow{2}{*}{$\begin{array}{c}\text { Population } \\
\text { (Number, Age, } \\
\text { Diagnosis) }\end{array}$} & \multicolumn{4}{|c|}{ Environmental Domains } & \multirow[t]{2}{*}{ Summary of Main Findings } \\
\hline & & & & $\begin{array}{c}\text { Products \& } \\
\text { Technology \& } \\
\text { Natural } \\
\text { Environment }\end{array}$ & $\begin{array}{c}\text { Support \& } \\
\text { Relationships }\end{array}$ & Attitudes & $\begin{array}{c}\text { Services, } \\
\text { Systems \& } \\
\text { Policies }\end{array}$ & \\
\hline $\begin{array}{c}\text { Sung \& Connor } \\
{[27]} \\
\text { USA }\end{array}$ & $\begin{array}{l}\text { To investigate career behaviour, } \\
\text { self-efficacy, goals, and } \\
\text { contextual supports and barriers } \\
\text { as predictors of choice actions } \\
\text { and work participation among } \\
\text { transition-age individuals with } \\
\text { epilepsy. }\end{array}$ & $\begin{array}{l}\text { Quantitative- } \\
\text { cross-sectional } \\
\text { design }\end{array}$ & $\begin{array}{c}n=90 \\
\text { Aged 18-25 } \\
\text { Epilepsy }\end{array}$ & & $\checkmark$ & & & $\begin{array}{l}\text { Facilitators: } \\
\text { - Work participation was positively associated (moderate) with } \\
\text { supports (e.g., having a mentor to guide and encourage) and } \\
\text { negatively correlated with barriers (e.g., lack of } \\
\text { employer's support) } \\
58 \% \text { of the variance in work participation was accounted for by } \\
\text { environmental supports from family, friends and processionals } \\
(\beta=0.238) \text {, self-efficacy with making career decisions }(\beta=0.221) \text {, } \\
\text { and expectations related to the outcomes of working }(\beta=0.460)\end{array}$ \\
\hline $\begin{array}{l}\text { Butterworth } \\
\text { et al. [28] } \\
\text { USA }\end{array}$ & $\begin{array}{l}\text { To better understand the } \\
\text { relationship between the } \\
\text { characteristics of the workplace } \\
\text { and the levels of support and } \\
\text { social inclusion experienced by } \\
\text { employees with a disability. }\end{array}$ & $\begin{array}{l}\text { Qualitative-part } \\
\text { of larger study }\end{array}$ & $\begin{array}{l}n=8 \text { young adults } \\
\text { Aged } * 17-22 \\
\text { Developmental } \\
\text { disability }\end{array}$ & & $\checkmark$ & & $\checkmark$ & $\begin{array}{l}\text { Facilitators: } \\
\text { - } \quad \text { Managers showing personal interest in employees } \\
\text { - } \quad \text { High sense of teamwors of support (social opportunities, emphasis on shared } \\
\text { job responsibilities, employee trainings for multiple jobs) } \\
\text { - Creating multiple in-depth relationships crossing over different } \\
\quad \text { life contexts }\end{array}$ \\
\hline $\begin{array}{l}\text { Barf et al. [29] } \\
\text { Netherlands }\end{array}$ & $\begin{array}{l}\text { To examine participation } \\
\text { restrictions of a large group of } \\
\text { young adults born with SB in } \\
\text { relation to disease characteristics, } \\
\text { activity limitations and } \\
\text { perceived hindrances for } \\
\text { participation. }\end{array}$ & $\begin{array}{l}\text { Quantitative- } \\
\text { cross-sectional } \\
\text { study }\end{array}$ & $\begin{array}{c}n=179 \\
\text { Aged } * 16-25 \text { years } \\
(\text { mean }=21) \\
\quad \text { SB }\end{array}$ & $\checkmark$ & & & & $\begin{array}{l}\text { Barriers: } \\
\text { - } \quad \text { Building inaccessibility } \\
\text { - } \quad \text { Traveral costs } \\
\quad \quad \text { distance to workplace }\end{array}$ \\
\hline $\begin{array}{c}\text { Greenbaum [30] } \\
\text { USA }\end{array}$ & $\begin{array}{l}\text { To obtain information on } \\
\text { employment and social status of } \\
\text { college alumni (1980-1992) with } \\
\text { learning disabilities. }\end{array}$ & $\begin{array}{l}\text { Quantitative- } \\
\text { cross-sectional } \\
\text { study }\end{array}$ & $\begin{array}{c}n=49 \\
\text { Mean age }=26 \\
\text { Learning disability }\end{array}$ & $\checkmark$ & $\checkmark$ & $\checkmark$ & $\checkmark$ & $\begin{array}{l}\text { Facilitators: } \\
\text { - } \quad \text { Family support } \\
\text { - College education and higher socioeconomic status } \\
\text { Barriers: } \\
\text { - Only } 20 \% \text { of employees disclosed their diagnosis due to concerns } \\
\text { - } \quad \text { Emout discrimination } \\
\text { outlineed's lack the knowledge or willingness to exercise rights as asitation Act of } 1973 \text { and the Americans with } \\
\text { Disabilities Act of } 1990\end{array}$ \\
\hline $\begin{array}{l}\text { Honey et al. [31] } \\
\text { Australia }\end{array}$ & $\begin{array}{l}\text { To investigate the transitions } \\
\text { between full-time, part-time and } \\
\text { non-employment for young } \\
\text { people with and without } \\
\text { disabilities. }\end{array}$ & $\begin{array}{l}\text { Retrospective-- } \\
\text { longitudinal } \\
\text { study }\end{array}$ & $\begin{array}{l}\mathrm{n}=766 \text { with } \\
\text { disability, } \mathrm{n}=5008 \\
\text { without disability } \\
\text { Aged * } 15-29 \\
\text { Disability not } \\
\text { specified }\end{array}$ & & $\checkmark$ & & $\checkmark$ & $\begin{array}{l}\text { Barriers: } \\
\text { - } \quad \text { Low social support and low education } \\
\text { Current employment status was strongly linked to previous } \\
\quad \text { employment status }\end{array}$ \\
\hline
\end{tabular}


Table 2. Cont

\begin{tabular}{|c|c|c|c|c|c|c|c|c|}
\hline \multirow{2}{*}{$\begin{array}{c}\text { Author, Year, } \\
\text { Country }\end{array}$} & \multirow[t]{2}{*}{ Aim of the Study } & \multirow[t]{2}{*}{ Study Design } & \multirow{2}{*}{$\begin{array}{c}\text { Population } \\
\text { (Number, Age, } \\
\text { Diagnosis) }\end{array}$} & \multicolumn{4}{|c|}{ Environmental Domains } & \multirow[t]{2}{*}{ Summary of Main Findings } \\
\hline & & & & $\begin{array}{c}\text { Products \& } \\
\text { Technology \& } \\
\text { Natural } \\
\text { Environment } \\
\end{array}$ & $\begin{array}{c}\text { Support \& } \\
\text { Relationships }\end{array}$ & Attitudes & $\begin{array}{l}\text { Services, } \\
\text { Systems \& } \\
\text { Policies }\end{array}$ & \\
\hline $\begin{array}{l}\text { Toldrá \& } \\
\text { Santosb [32] } \\
\text { Brazil }\end{array}$ & $\begin{array}{l}\text { To identify facilitators and } \\
\text { barriers faced by people with } \\
\text { disabilities in the workforce. }\end{array}$ & $\begin{array}{l}\text { Qualitative- } \\
\text { Discourse of the } \\
\text { collective } \\
\text { subject matter } \\
\text { method }\end{array}$ & $\begin{array}{l}n=10 \\
\text { Aged 21-36, } \\
\text { SCI, MD, CP, } \\
\text { blindness, spinal } \\
\text { amiotrophy, multiple } \\
\text { arthrogiposis, } \\
\text { congenital } \\
\text { malformation }\end{array}$ & $\checkmark$ & $\checkmark$ & $\checkmark$ & $\checkmark$ & $\begin{array}{l}\text { Facilitators: } \\
\text { - } \quad \text { Building social relationships in the workplace } \\
\text { Barriers: } \\
\text { - } \quad \text { Prejudice } \\
\text { - Inadequate employee support by companies for } \\
\quad \text { workplace accommodations }\end{array}$ \\
\hline $\begin{array}{l}\text { Solstad \& } \\
\text { Schreuer [33] } \\
\text { USA } \\
\text { \& Norway }\end{array}$ & $\begin{array}{l}\text { To explore from a cross-national } \\
\text { perspective, the complexities of } \\
\text { workplace accommodation } \\
\text { policies in action. }\end{array}$ & $\begin{array}{l}\text { Qualitative } \\
\text { study }\end{array}$ & $\begin{array}{c}n=29 \\
\text { Age }{ }^{*} \\
\text { U.S.A: } 22-39 \text { (median } \\
\text { 31) Norway: } 24-43 \text {. } \\
\text { (median:33) } \\
\text { 2/3 CP, osteogenesis } \\
\text { imperfecta, or SB. }\end{array}$ & $\checkmark$ & & & $\checkmark$ & $\begin{array}{l}\text { Facilitators: } \\
\text { - Flexible or reduced work hours } \\
\text { - Accessibility to transit, physical work environment, assistive } \\
\text { - technology, and job coaching } \\
\text { Barriers: } \\
\text { - Timely to work from home } \\
\text { - Lack of employerer's awareness about necessary accommodations } \\
\text { - Costs/length of implementing accommodations }\end{array}$ \\
\hline $\begin{array}{l}\text { Lindsay et al. } \\
\text { [34] } \\
\text { Holland and } \\
\text { Canada }\end{array}$ & $\begin{array}{l}\text { To explore the facilitators, } \\
\text { barriers and experiences of } \\
\text { employment and post-secondary } \\
\text { education among youth and } \\
\text { young adults with spina bifida; } \\
\text { and their variations between } \\
\text { youth and young adults with } \\
\text { spina bifida, their parents and } \\
\text { health care providers. }\end{array}$ & $\begin{array}{l}\text { Qualitative-- } \\
\text { secondary } \\
\text { analysis from } \\
\text { larger study }\end{array}$ & $\begin{array}{c}n=12 \text { youths, } 11 \\
\text { parents and } 12 \\
\text { health care providers } \\
\text { Aged 19-25 } \\
\text { SB }\end{array}$ & $\checkmark$ & $\checkmark$ & $\checkmark$ & $\checkmark$ & $\begin{array}{l}\text { Facilitators: } \\
\text { - Support from family and peers, participation in internships } \\
\text { through school } \\
\text { - Having accommodations made through a disability service at the } \\
\text { post-secondary educational level } \\
\text { Barriers: } \\
\text { - Lack of supports and resources, limited options for accessible jobs } \\
\text { transportation, over-protective parents, stigma and discrimination } \\
\text { employer stereotypes, lack of professional support to find } \\
\text { employment, and work tasks unfit with the employee's } \\
\text { physical skills }\end{array}$ \\
\hline $\begin{array}{c}\text { Sherer et al. [35] } \\
\text { USA }\end{array}$ & $\begin{array}{l}\text { To explore the prognostic value } \\
\text { of self-reported traits, problems, } \\
\text { strengths and environmental } \\
\text { barriers or facilitators for } \\
\text { participation outcomes in } \\
\text { persons with traumatic brain } \\
\text { injury (TBI). }\end{array}$ & $\begin{array}{l}\text { Systematic } \\
\text { review }\end{array}$ & $\begin{array}{c}n=63 \text { articles } \\
>17 \text { years old } \\
\text { TBI }\end{array}$ & $\checkmark$ & $\checkmark$ & & $\checkmark$ & 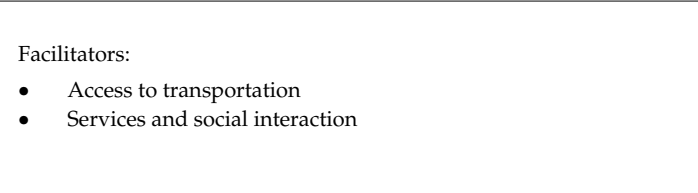 \\
\hline
\end{tabular}


Table 2. Cont

\begin{tabular}{|c|c|c|c|c|c|c|c|c|}
\hline \multirow{2}{*}{$\begin{array}{l}\text { Author, Year, } \\
\text { Country }\end{array}$} & \multirow[t]{2}{*}{ Aim of the Study } & \multirow[t]{2}{*}{ Study Design } & \multirow{2}{*}{$\begin{array}{c}\text { Population } \\
\text { (Number, Age, } \\
\text { Diagnosis) }\end{array}$} & \multicolumn{4}{|c|}{ Environmental Domains } & \multirow[t]{2}{*}{ Summary of Main Findings } \\
\hline & & & & $\begin{array}{c}\text { Products \& } \\
\text { Technology \& } \\
\text { Natural } \\
\text { Environment }\end{array}$ & $\begin{array}{c}\text { Support \& } \\
\text { Relationships }\end{array}$ & Attitudes & $\begin{array}{l}\text { Services, } \\
\text { Systems \& } \\
\text { Policies }\end{array}$ & \\
\hline $\begin{array}{c}\text { Törnbom et al. } \\
{[36]} \\
\text { Sweden }\end{array}$ & $\begin{array}{c}\text { To compare work participation } \\
\text { in } 2009 \text { with } 1997 \text { in individuals } \\
\text { with cerebral palsy and spina } \\
\text { bifida. }\end{array}$ & $\begin{array}{l}\text { Longitudinal- } \\
\text { descriptive } \\
\text { study }\end{array}$ & $\begin{array}{c}n=30 \\
\text { Mean age 24 } \\
\text { CP and SB }\end{array}$ & $\checkmark$ & & & $\checkmark$ & $\begin{array}{l}\text { Facilitators: } \\
\text { - Access to personal assistance } \\
\text { - } \quad \text { Adequate transportation } \\
\text { - } \quad \text { Continuing educestion } \\
\text { Barriers: } \\
\text { - } 29 \% \text { of employemesidies to employers } \\
\text { in } 1997 \text { compared transportation for people with disabilities } \\
\text { criticized because of frequent late arrivals and long travel times }\end{array}$ \\
\hline $\begin{array}{l}\text { Lindsay [37] } \\
\text { Canada }\end{array}$ & $\begin{array}{l}\text { To explore the characteristics } \\
\text { associated with disabled youth } \\
\text { who are employed and the types } \\
\text { of employment they are engaged } \\
\text { in. }\end{array}$ & $\begin{array}{l}\text { Retrospective- } \\
\text { cross-sectional } \\
\text { study }\end{array}$ & $\begin{array}{c}n=5234 \\
\text { Aged }{ }^{*} 15-24 \text { years } \\
\text { old } \\
\text { mobility, hearing, } \\
\text { vision, } \\
\text { communication, } \\
\text { cognitive } \\
\text { impairment }\end{array}$ & $\checkmark$ & $\checkmark$ & & $\checkmark$ & $\begin{array}{l}\text { Facilitators: } \\
\text { - } \quad \text { Access to vehicle } \\
\text { - } \quad \text { Feing in urban setting } \\
\end{array}$ \\
\hline $\begin{array}{l}\text { De Beer et al. } \\
\quad[38] \\
\text { Netherlands }\end{array}$ & $\begin{array}{l}\text { To determine facilitators and } \\
\text { barriers associated with } \\
\text { participation in work of } \\
\text { individuals with developmental } \\
\text { disabilities, classified according } \\
\text { to the dimensions of the ICF. }\end{array}$ & $\begin{array}{l}\text { Systematic } \\
\text { review }\end{array}$ & $\begin{array}{c}n=256 \\
\text { Mean age }=33 \\
\text { Developmental } \\
\text { dyslexia and/or } \\
\text { learning disability }\end{array}$ & $\checkmark$ & $\checkmark$ & $\checkmark$ & $\checkmark$ & $\begin{array}{l}\text { Facilitators: } \\
\text { - Support from employer and colleagues } \\
\text { Barriers: } \\
\text { - } \quad \text { Support and relationships, attitudes of co-workers, working } \\
\quad \text { conditions, legal services, systems and policies, social security } \\
\text { service systems, policies, SES and education level. }\end{array}$ \\
\hline $\begin{array}{l}\text { Ripat, \& } \\
\text { Woodgate [39] } \\
\text { Canada }\end{array}$ & $\begin{array}{l}\text { To present experiences and use } \\
\text { of assistive technology (AT) from } \\
\text { young adults in supporting their } \\
\text { productivity. }\end{array}$ & $\begin{array}{l}\text { Qualitative- } \\
\text { grounded } \\
\text { theory and } \\
\text { participatory } \\
\text { research study }\end{array}$ & $\begin{array}{l}n=20 \\
\text { Aged }{ }^{*} 17-35 \\
\text { SCI, CP, SB, MS, } \\
\text { non-verbal disorders, } \\
\text { dyslexia, visual } \\
\text { impairment, Usher's } \\
\text { and Ehlers-Danlos } \\
\text { Syndrome }\end{array}$ & $\checkmark$ & & $\checkmark$ & $\checkmark$ & $\begin{array}{l}\text { Facilitators: } \\
\text { - Access to AT } \\
\text { Barriers: } \\
\text { - } \quad \text { AT was sometimes seen as unnecessary by co-workers and was } \\
\text { viewed as a privilege. }\end{array}$ \\
\hline
\end{tabular}


Table 2. Cont

\begin{tabular}{|c|c|c|c|c|c|c|c|c|}
\hline \multirow{2}{*}{$\begin{array}{l}\text { Author, Year, } \\
\text { Country }\end{array}$} & \multirow[t]{2}{*}{ Aim of the Study } & \multirow[t]{2}{*}{ Study Design } & \multirow{2}{*}{$\begin{array}{c}\text { Population } \\
\text { (Number, Age, } \\
\text { Diagnosis) }\end{array}$} & \multicolumn{4}{|c|}{ Environmental Domains } & \multirow[t]{2}{*}{ Summary of Main Findings } \\
\hline & & & & $\begin{array}{c}\text { Products \& } \\
\text { Technology \& } \\
\text { Natural } \\
\text { Environment }\end{array}$ & $\begin{array}{c}\text { Support \& } \\
\text { Relationships }\end{array}$ & Attitudes & $\begin{array}{c}\text { Services, } \\
\text { Systems \& } \\
\text { Policies }\end{array}$ & \\
\hline $\begin{array}{c}\text { Darrah et al. } \\
\text { [40] } \\
\text { Canada }\end{array}$ & $\begin{array}{l}\text { To understand the contribution } \\
\text { of educational, employment, } \\
\text { transportation and assured } \\
\text { income service programs to the } \\
\text { successful transition of young } \\
\text { adults with motor disabilities to } \\
\text { adulthood. } \\
\end{array}$ & $\begin{array}{l}\text { Qualitative } \\
\text { study }\end{array}$ & $\begin{array}{c}n=76 \\
\text { Aged 20-30 } \\
\text { CP and SB }\end{array}$ & $\checkmark$ & & & $\checkmark$ & $\begin{array}{l}\text { Barriers: } \\
\text { - Concerns with having reduced income benefit, lack of accessible } \\
\text { transportation, limited post-secondary training opportunities, lack } \\
\text { of employment accommodations, and a lack of services available } \\
\text { to assist with finding a job. }\end{array}$ \\
\hline $\begin{array}{l}\text { Morash-Macneil } \\
\text { et al. [41] } \\
\text { USA }\end{array}$ & $\begin{array}{l}\text { To investigate the efficacy of } \\
\text { assistive technology (AT) in } \\
\text { improving the ability to complete } \\
\text { work tasks independently and } \\
\text { efficiently for individuals with } \\
\text { intellectual disabilities. }\end{array}$ & $\begin{array}{c}\text { Systematic } \\
\text { review }\end{array}$ & $\begin{array}{c}\mathrm{n}=29 \\
\text { Aged *: } 15-24 \\
\text { ID }\end{array}$ & $\checkmark$ & & & & $\begin{array}{l}\text { Facilitators: } \\
\text { - Appropriate assistive technology such as portable electronic } \\
\text { devices resulted in improved employment skills like task } \\
\text { completion, time management and increased productivity }\end{array}$ \\
\hline $\begin{array}{c}\text { Holwerda et al. } \\
\quad[42] \\
\text { Netherlands }\end{array}$ & $\begin{array}{l}\text { To investigate factors that predict } \\
\text { work participation, finding and } \\
\text { maintaining employment of } \\
\text { young adults with ASD and as } \\
\text { ADD. }\end{array}$ & $\begin{array}{l}\text { Longitudinal - } \\
\text { cohort study }\end{array}$ & $\begin{array}{c}n=563 \\
\text { Aged * } 15-27 \\
(m e a n=19.4) \\
\text { ASD and ADHD }\end{array}$ & & $\checkmark$ & $\checkmark$ & & $\begin{array}{l}\text { Facilitators: } \\
\text { - Positive attitude and support from parents and others at work } \\
\text { Barriers: } \\
\text { - High parental support: overprotective parents might prevent } \\
\text { children from finding employment }\end{array}$ \\
\hline $\begin{array}{l}\text { Tobias \& } \\
\text { Mukhopadhyay } \\
{[43]} \\
\text { Namibia }\end{array}$ & $\begin{array}{l}\text { To identify the social experiences } \\
\text { of individuals with a visual } \\
\text { impairment in rural Namibia and } \\
\text { to provide suggestions on how to } \\
\text { include them in the community. }\end{array}$ & $\begin{array}{l}\text { Qualitative } \\
\text { study }\end{array}$ & $\begin{array}{c}n=9 \\
\text { Aged } 30 \text { to } \\
\text { 90-information was } \\
\text { extracted from } 3 \\
\text { participants who } \\
\text { were in their 30s } \\
\text { Vision impairment }\end{array}$ & & $\checkmark$ & $\checkmark$ & $\checkmark$ & $\begin{array}{l}\text { Barriers: } \\
\text { - } \quad \text { Lack of social and family support restricted access to education } \\
\text { The abilities of participants with vision impairment were } \\
\text { undermined due to being viewed as dependent. } \\
\text { Policies promoting the employment of people with visual } \\
\text { impairments were not enacted. }\end{array}$ \\
\hline $\begin{array}{c}\text { Hagner et al. } \\
\text { [44] } \\
\text { USA }\end{array}$ & $\begin{array}{l}\text { To clarify the current } \\
\text { implemented strategies to } \\
\text { facilitate the involvement of } \\
\text { natural support resources in the } \\
\text { employment process. }\end{array}$ & $\begin{array}{l}\text { Qualitative } \\
\text { study }\end{array}$ & $\begin{array}{l}n=33 \text { vocational } \\
\text { specialists/staff } \\
\text { Age of participants } \\
\text { not specified as } \\
\text { study was completed } \\
\text { from perspective of } \\
\text { vocational support } \\
\text { specialists }\end{array}$ & & $\checkmark$ & & $\checkmark$ & $\begin{array}{l}\text { Facilitators: } \\
\text { - Support from family and friends, social interaction among } \\
\text { co-workers, and inclusion of company personnel in the training of } \\
\text { an employee with a disability } \\
\text { Barriers: } \\
\text { - Low family involvement: unwillingness to assist in job searching } \\
\text { due to lack of time, being overprotective, embarrassment related } \\
\text { the youth's disability or not believing that the youth could succeed } \\
\text { in a job } \\
\text { - Lack of flexibility of company resources and resentment or } \\
\text { discrimination toward individuals with disabilities }\end{array}$ \\
\hline
\end{tabular}


Table 2. Cont

\begin{tabular}{|c|c|c|c|c|c|c|c|c|}
\hline \multirow[t]{2}{*}{$\begin{array}{l}\text { Author, Year, } \\
\text { Country }\end{array}$} & \multirow[t]{2}{*}{ Aim of the Study } & \multirow[t]{2}{*}{ Study Design } & \multirow{2}{*}{$\begin{array}{c}\text { Population } \\
\text { (Number, Age, } \\
\text { Diagnosis) }\end{array}$} & \multicolumn{4}{|c|}{ Environmental Domains } & \multirow[t]{2}{*}{ Summary of Main Findings } \\
\hline & & & & $\begin{array}{l}\text { Products \& } \\
\text { Technology \& } \\
\text { Natural } \\
\text { Environment }\end{array}$ & $\begin{array}{c}\text { Support \& } \\
\text { Relationships }\end{array}$ & Attitudes & $\begin{array}{l}\text { Services, } \\
\text { Systems \& } \\
\text { Policies }\end{array}$ & \\
\hline $\begin{array}{l}\text { Petner-Arrey } \\
\text { et al. [45] } \\
\text { Canada }\end{array}$ & $\begin{array}{l}\text { To better understand the } \\
\text { experiences of people with } \\
\text { intellectual or development } \\
\text { disability (IDD) gaining and } \\
\text { keeping productivity roles }\end{array}$ & $\begin{array}{l}\text { Qualitative- } \\
\text { grounded } \\
\text { theory }\end{array}$ & $\begin{array}{c}n=74(13 \text { persons } \\
\text { with IDD, } 21 \\
\text { caregivers, } 40 \text { pairs } \\
\text { of caregivers and } \\
\text { people with IDD } \\
\text { Aged } * 21-54 \\
\text { (mean }=27)\end{array}$ & & $\checkmark$ & & & $\begin{array}{l}\text { Facilitators: } \\
\text { - Parents and social networks facilitated acquiring and sustaining } \\
\text { employment providing on the job assistance, helping employees to } \\
\text { understand job expectations and providing advocate support }\end{array}$ \\
\hline $\begin{array}{l}\text { Lindstrom et al. } \\
{[46]} \\
\text { USA }\end{array}$ & $\begin{array}{l}\text { To examine the career } \\
\text { development process and } \\
\text { postschool employment } \\
\text { outcomes for a sample of } \\
\text { individuals with disabilities. }\end{array}$ & $\begin{array}{l}\text { Qualitative-case } \\
\text { study }\end{array}$ & $\begin{array}{l}n=8 \\
\text { Aged 25-28 } \\
\text { learning \& emotional } \\
\text { disability, orthopedic } \\
\text { impairment }\end{array}$ & & $\checkmark$ & & & $\begin{array}{l}\text { Facilitators: } \\
\text { - } \quad \text { Previous work experience } \\
\text { - } \quad \text { Positive interactions with colleagues } \\
\end{array}$ \\
\hline $\begin{array}{c}\text { Lindsay et al. } \\
\quad[47] \\
\text { Canada }\end{array}$ & $\begin{array}{l}\text { To explore the extent to which } \\
\text { youths with physical disabilities } \\
\text { encounter barriers to } \\
\text { employment compared to their } \\
\text { typically developing peers. }\end{array}$ & $\begin{array}{l}\text { Qualitative-part } \\
\text { of larger } \\
\text { multi-method } \\
\text { study }\end{array}$ & $\begin{array}{c}n=31 \text { youth (16 typ. } \\
\text { Dev. And } 15 \text { with } \\
\text { disability); } 9 \text { youth } \\
\text { employers, } 10 \text { job } \\
\text { counselors } \\
\text { Aged } * 16-19 \\
\text { CP, MD, } \\
\text { myoltubularmyopathy, } \\
\text { central core } \\
\text { myopathy, } \\
\text { Guillianbarre, } \\
\text { scoliosis }\end{array}$ & $\checkmark$ & $\checkmark$ & $\checkmark$ & $\checkmark$ & $\begin{array}{l}\text { Facilitators: } \\
\text { - Peer influence helped motivate youth with disabilities to seek } \\
\text { out employment } \\
\text { - Financial incentive for employers to hire employees } \\
\text { with disabilities } \\
\text { Barriers: } \\
\text { - Parental overprotection } \\
\text { - Inadequate development of social and communication skills } \\
\text { needed for the workplace } \\
\text { - Inaccessible environments and challenges with advocating } \\
\text { - for accommodations } \\
\text { as a result of omped to disclosing diagnosis, perceived disadvantages stereotypes and potential loss of } \\
\text { disability benefits } \\
\text { Employers' lack of knowledge on how to adapt the environment, } \\
\text { training procedures and tasks to support employees } \\
\text { with disabilities } \\
\text { - Lack of funding to support employers' awareness of disability }\end{array}$ \\
\hline $\begin{array}{l}\text { Reid \& Bray [48] } \\
\text { New Zealand }\end{array}$ & $\begin{array}{l}\text { To present opinions of workers, } \\
\text { supporters and employers and to } \\
\text { offer strategies for greater } \\
\text { employment rates and } \\
\text { better-informed decisions by } \\
\text { education, training and support } \\
\text { agencies. }\end{array}$ & $\begin{array}{l}\text { Qualitative } \\
\text { study }\end{array}$ & $\begin{array}{c}n=17 \text { workers, } 3 \\
\text { employers, } 7 \text { support } \\
\text { people, } 2 \text { experts on } \\
\text { employment } \\
\text { Mean age early } 30 \text { s } \\
\text { (range 24-50) } \\
\text { ID }\end{array}$ & & $\checkmark$ & & $\checkmark$ & $\begin{array}{l}\text { Facilitators: } \\
\text { - Engaging in social activities, having flexible work hours, access to } \\
\text { services to assist with finding and maintaining employment }\end{array}$ \\
\hline
\end{tabular}


Table 2. Cont

\begin{tabular}{|c|c|c|c|c|c|c|c|c|}
\hline \multirow{2}{*}{$\begin{array}{l}\text { Author, Year, } \\
\text { Country }\end{array}$} & \multirow[t]{2}{*}{ Aim of the Study } & \multirow[t]{2}{*}{ Study Design } & \multirow{2}{*}{$\begin{array}{c}\text { Population } \\
\text { (Number, Age, } \\
\text { Diagnosis) }\end{array}$} & \multicolumn{4}{|c|}{ Environmental Domains } & \multirow[t]{2}{*}{ Summary of Main Findings } \\
\hline & & & & $\begin{array}{c}\text { Products \& } \\
\text { Technology \& } \\
\text { Natural } \\
\text { Environment }\end{array}$ & $\begin{array}{c}\text { Support \& } \\
\text { Relationships }\end{array}$ & Attitudes & $\begin{array}{c}\text { Services, } \\
\text { Systems \& } \\
\text { Policies }\end{array}$ & \\
\hline $\begin{array}{l}\text { Scott et al. [49] } \\
\text { Australia }\end{array}$ & $\begin{array}{l}\text { To present and contrast the } \\
\text { viewpoints of adults with ASD } \\
\text { and employers for successful } \\
\text { employment and to explore how } \\
\text { these viewpoints impact the } \\
\text { process of employment. }\end{array}$ & $\begin{array}{l}\text { Qualitative-Q } \\
\text { method }\end{array}$ & $\begin{array}{l}n=40 \text { employees } \\
n=35 \text { employers } \\
\text { Employee: Mean } \\
\text { age: } 29.1 \text { Median: } 26 \\
\text { Employer: Mean age: } \\
\text { 44.6 Median: } 44 \\
\text { ASD } \\
\end{array}$ & $\checkmark$ & $\checkmark$ & $\checkmark$ & $\checkmark$ & $\begin{array}{l}\text { Facilitators: } \\
\text { - Having an inclusive work environment, continued support from } \\
\text { an employment support worker after hiring, approachable } \\
\text { manager, and investing in inclusion } \\
\text { - Workplaces that valued, encouraged and supported the employee }\end{array}$ \\
\hline $\begin{array}{l}\text { Li EPY [50] } \\
\text { China }\end{array}$ & $\begin{array}{l}\text { To look critically at the } \\
\text { competitive employment } \\
\text { experiences of people with } \\
\text { intellectual disability and at their } \\
\text { perception of social barriers that } \\
\text { could affect their ambition to get } \\
\text { a job in the community. }\end{array}$ & $\begin{array}{l}\text { Qualitative } \\
\text { study }\end{array}$ & $\begin{array}{l}n=18 \\
\text { Aged * } 22-43 \\
(\text { mean }=28.7) \\
\quad \text { Mild ID }\end{array}$ & & $\checkmark$ & $\checkmark$ & $\checkmark$ & $\begin{array}{l}\text { Facilitators: } \\
\text { - Positive attitudes and support from employers and colleagues } \\
\text { Assistance from professionals for employment, disability } \\
\text { education for public and employers, training programs to support } \\
\text { the development of work and social skills } \\
\text { Barriers: } \\
\text { - Stress of the interview and negative attitudes of the employer } \\
\text { - Workplace discrimination, poor relationships with co-workers } \\
\text { and employer }\end{array}$ \\
\hline $\begin{array}{c}\text { Roessler et al. } \\
\text { [51] } \\
\text { USA }\end{array}$ & $\begin{array}{l}\text { To determine whether the nature } \\
\text { and scope of workplace } \\
\text { discrimination is different for } \\
\text { youths with epilepsy as } \\
\text { compared to other types of } \\
\text { disabilities. }\end{array}$ & $\begin{array}{c}\text { Quantitative- } \\
\text { comparison } \\
\text { analysis }\end{array}$ & $\begin{array}{l}\text { Epilepsy: } n=555 \\
\text { General Disability: } \\
n=12,663 \\
\text { allegations Aged } \\
18-25 \\
\text { Epilepsy }\end{array}$ & & & $\checkmark$ & $\checkmark$ & $\begin{array}{l}\text { Barriers: } \\
\text { - Job retention was impacted by allegations of discrimination, } \\
\text { stereotypes about epilepsy, and frequently being hired into less } \\
\text { secure entry level jobs } \\
\text { - Unlawful discharge was higher in youths with epilepsy compared } \\
\text { to the general disability grouping }\end{array}$ \\
\hline $\begin{array}{l}\text { Wilson-Kovacs } \\
\text { et al. [52] } \\
\text { United } \\
\text { Kingdom }\end{array}$ & $\begin{array}{l}\text { To present barriers, problems } \\
\text { and potential solutions to } \\
\text { challenges that members of } \\
\text { marginalized groups encounter } \\
\text { in the workplace. }\end{array}$ & $\begin{array}{l}\text { Qualitative } \\
\text { study }\end{array}$ & $\begin{array}{l}\quad n=14 \\
\text { Data presented for } \\
\text { those } 35 \text { years old } \\
\text { Polio, hearing loss, } \\
\text { MS, dyslexia }\end{array}$ & & & $\checkmark$ & $\checkmark$ & $\begin{array}{l}\text { Barriers: } \\
\text { - Lack of feedback provision and inclusion in decision making, } \\
\text { perceptions of employee ability, discrimination, lack of necessary } \\
\text { accommodations to support integration into workplace culture }\end{array}$ \\
\hline
\end{tabular}


Table 2. Cont

\begin{tabular}{|c|c|c|c|c|c|c|c|c|}
\hline \multirow[t]{2}{*}{$\begin{array}{l}\text { Author, Year, } \\
\text { Country }\end{array}$} & \multirow[t]{2}{*}{ Aim of the Study } & \multirow[t]{2}{*}{ Study Design } & \multirow{2}{*}{$\begin{array}{c}\text { Population } \\
\text { (Number, Age, } \\
\text { Diagnosis) } \\
\end{array}$} & \multicolumn{4}{|c|}{ Environmental Domains } & \multirow[t]{2}{*}{ Summary of Main Findings } \\
\hline & & & & $\begin{array}{c}\text { Products \& } \\
\text { Technology \& } \\
\text { Natural } \\
\text { Environment }\end{array}$ & $\begin{array}{c}\text { Support \& } \\
\text { Relationships }\end{array}$ & Attitudes & $\begin{array}{l}\text { Services, } \\
\text { Systems \& } \\
\text { Policies }\end{array}$ & \\
\hline $\begin{array}{l}\text { Lieketseng \& } \\
\text { Lorenzo [53] } \\
\text { South Africa }\end{array}$ & $\begin{array}{l}\text { To describe the capacity of } \\
\text { service providers in facilitating } \\
\text { the participation of disabled } \\
\text { youth in economic development } \\
\text { opportunities }\end{array}$ & $\begin{array}{l}\text { Qualitative-case } \\
\text { study }\end{array}$ & $\begin{array}{l}n=5 \text { disabled youth, } \\
4 \text { family members } \\
\text { and } 6 \text { service } \\
\text { providers } \\
\text { Age only specified as } \\
\text { youth } \\
\text { Intellectual or } \\
\text { sensory impairment }\end{array}$ & & & $\checkmark$ & $\checkmark$ & $\begin{array}{l}\text { Facilitators: } \\
\text { - Disability grants for young adults with disability who want to start } \\
\text { their own business } \\
\text { Barriers: } \\
\text { - Lack of knowledge about the need for inclusion and how to } \\
\text { support it, attitudes, stereotypes about disabled youths' } \\
\text { participation in the workplace and lack of enactment of } \\
\text { inclusion policies } \\
\text { - Disability grants for young adults with disability limit } \\
\text { work opportunities }\end{array}$ \\
\hline $\begin{array}{c}\text { Hagner \& } \\
\text { Cooney [54] } \\
\text { USA }\end{array}$ & $\begin{array}{l}\text { To locate individuals with autism } \\
\text { who were successfully employed } \\
\text { at jobs in the community and to } \\
\text { identify the factors that } \\
\text { contributed to their success. }\end{array}$ & $\begin{array}{l}\text { Qualitative } \\
\text { study }\end{array}$ & $\begin{array}{c}n=14 \\
\text { Aged * 23-36 } \\
\text { ASD }\end{array}$ & & $\checkmark$ & & $\checkmark$ & $\begin{array}{l}\text { Facilitators: } \\
\text { - Job modifications such as maintaining a consistent schedule, } \\
\text { flexibility in job training, completing the sames set of work duties } \\
\text { and providing a checklist of tasks that need to be completed } \\
\text { - Supervisors providing information about social cues, rules and } \\
\text { direct instructions for work tasks } \\
\text { - For employees with ASD: coworkers initiating conversations and } \\
\text { providing feedback regarding social conventions }\end{array}$ \\
\hline & & & Total: & $17(55 \%)$ & $21(68 \%)$ & $15(48 \%)$ & \%) & \\
\hline
\end{tabular}

ID: Intellectual disability, SB: Spina bifida, SCI: Spinal cord injury, CP: Cerebral palsy, MS: Multiple sclerosis, TBI: Traumatic brain injury, MD: Muscular Dystrophy, ASD: Asperger Spectrum Disorder, ADHD: Attention deficit hyperactivity disorder. * Age: Studies with participants below 18 and above 35 years old are included because the mean age of participants in the study lies within 18-35 years old and/or they provide results for a subset of the participants within the range 18-35 years old. 
Table 3. Examples of environmental barriers and facilitators across the ICF domains.

\begin{tabular}{|c|c|c|}
\hline Domains & Facilitators & Barriers \\
\hline $\begin{array}{c}\text { Products \& } \\
\text { technology/Natural } \\
\text { environment }\end{array}$ & $\begin{array}{l}\text { - Physical alterations of the building and/or equipment, } \\
\text { accessible path, ramp, door handle, open and lock door system, } \\
\text { accessible bathroom, separate office, and adjustable desk [33] } \\
\text { - Specialized assistive technology such as voice recognition } \\
\text { software, special mouse, or computerized phone }[33,38,39,41] \\
\text { - Living in urban cities [37] }\end{array}$ & $\begin{array}{l}\text { - Transportation: lack of access, long distance }[29,33,36,40] \\
\text { - } \quad \text { Difficulty navigating public transport [34] } \\
\text { Inadequate lighting and temperature in the work setting [25] }\end{array}$ \\
\hline Support \& relationships & $\begin{array}{l}\text { - } \quad \text { Support from the employer [38] } \\
\text { - } \quad \text { Support from colleagues (e.g., proofread work) [30] } \\
\text { - } \quad \text { disability to work opportunities [45] } \\
\text { - } \text { fupport from parents (emotional, help with transportation, } \\
\text { - } \quad \text { Positive interactions with colleagues at work (e.g., lunch, } \\
\text { breaks) and during non-work related activities [28,44,46] } \\
\text { - } \quad \text { Receiving information from colleagues about etiquette and } \\
\text { dress code when participating in work-related social } \\
\text { conventions [54] } \\
\text { Approachable managers who promote fair workplace setting } \\
{[28,39,49]}\end{array}$ & $\begin{array}{l}\text { - } \quad \text { Poor relationships with employers and co-workers [50] } \\
\text { - } \quad \text { Overprotective parents [34] } \\
\text { - } \quad \text { Lack of support from parents in job search }[43,44]\end{array}$ \\
\hline Attitudes & $\begin{array}{l}\text { - Positive attitude from colleagues towards people with disability } \\
\text { [50] }\end{array}$ & 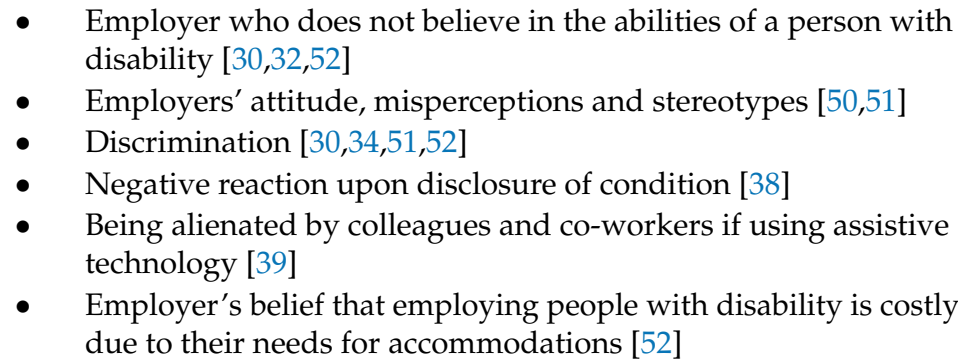 \\
\hline
\end{tabular}


Table 3. Cont.

\begin{tabular}{|c|c|c|}
\hline Domains & Facilitators & Barriers \\
\hline $\begin{array}{l}\text { Services, systems \& } \\
\text { policies }\end{array}$ & $\begin{array}{l}\text { - Settings that promote inclusion, fair workplace and high levels } \\
\text { of interactions and support [49] } \\
\text { - } \quad \text { Flexible work demands (schedules, workload) [30] } \\
\text { - Workplaces that value and recognize employee's skills and } \\
\text { contributions [49] } \\
\text { - } \text { Availability of support services and training programs for } \\
\text { employers as well as employees [44] } \\
\text { - } \text { Receiving assistance from professionals to find and maintain } \\
\text { - job [50] } \\
\text { Ongoing support from disability employment service providers } \\
\text { - } \quad \text { Policies that promote reasonable accommodations based on the } \\
\text { - } \quad \text { Wage subsidies in some countries such as Sweden [36] } \\
\text { - Opportunities to continuing education [36] }\end{array}$ & $\begin{array}{l}\text { - } \quad \text { Unpreparedness and lack of knowledge from the company on } \\
\text { - } \\
\text { - } \\
\text { - } \\
\text { Lack of acco of knowlable jobs [26] } \\
\text { - } \quad \text { Lack of clear policy implementation guides for workplaces } \\
\text { - } \quad \text { Certificates or diplomas that are not being recognized by } \\
\text { - } \quad \text { Eligibility for accommodations is based solely on medical } \\
\text { - } \quad \text { diagnosis rather than employee's needs or functional levels [33] } \\
\text { - } \quad \text { Slow delivery of services [44] } \\
\text { - } \quad \text { Inflexible work schedule [25] }\end{array}$ \\
\hline Other contextual factors & $\begin{array}{ll}\text { - } & \text { Higher family SES [30] } \\
\text { - } & \text { Higher level of education }[46,47] \\
\text { - } & \text { Fewer number of people in the household and lower SES [37] } \\
\text { Papation in internship and co-op programs [47] }\end{array}$ & $\begin{array}{l}\text { - } \quad \text { Few opportunities to participate in extracurricular or social } \\
\text { activities [47] } \\
\text { - } \quad \text { Lack of opportunities to volunteer [47] } \\
\text { - } \quad \text { Low education levels [31] }\end{array}$ \\
\hline
\end{tabular}




\section{Results}

Thirty-one articles met the inclusion criteria (See Figure 1). One hundred and ninety articles were excluded and the reason for exclusion is specified in Figure 1. The validation process, conducted by the rehabilitation specialist, resulted in 100\% agreement for included articles and $92 \%$ agreement for excluded articles. The initial disagreement on $8 \%$ of the excluded articles was resolved, and agreement was reached after a discussion with the senior researcher.

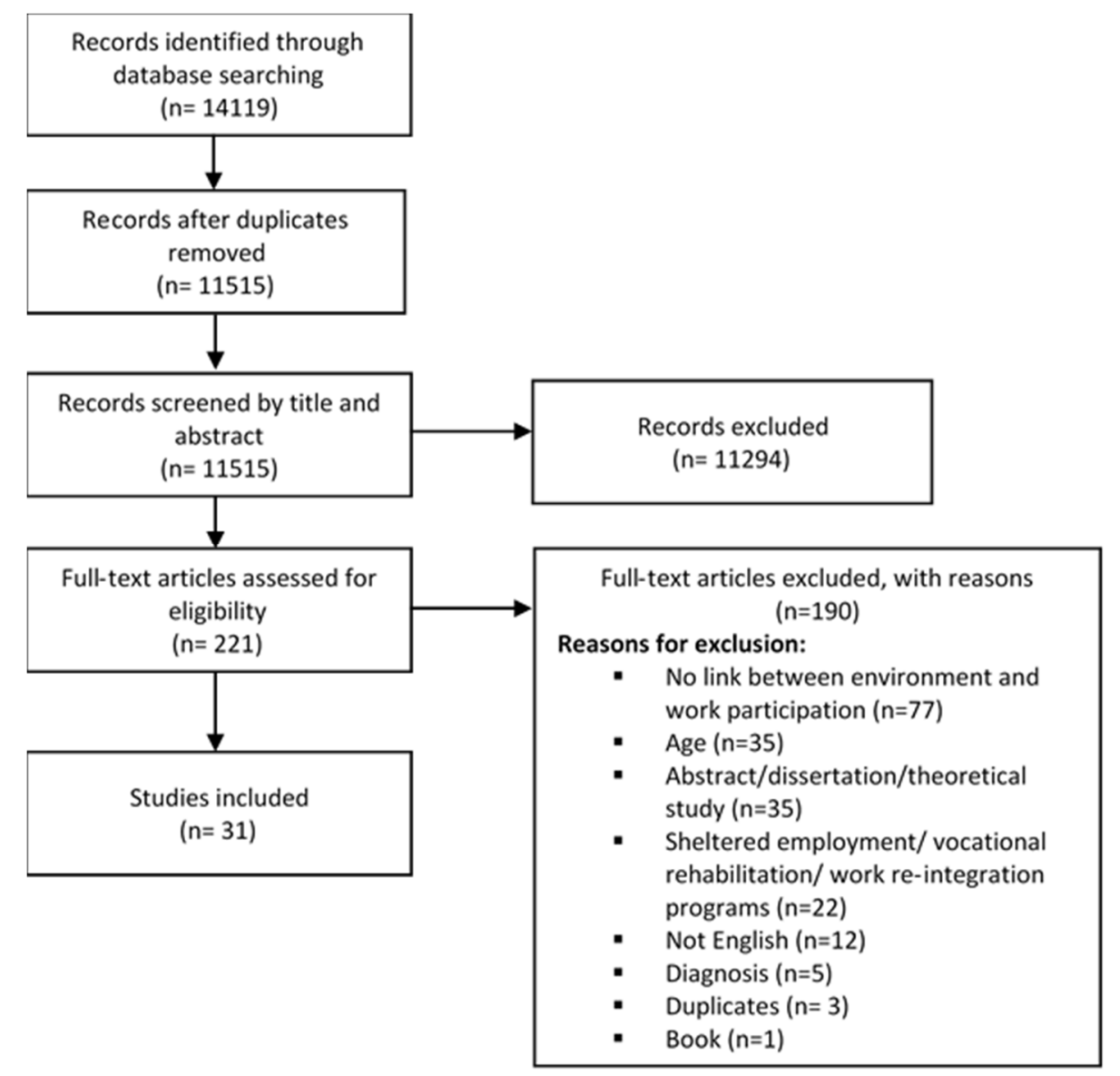

Figure 1. Flow chart of study selection process.

\subsection{Descriptive Summary of the Studies}

The selected studies were published between the years of 1995 and 2018 with $74 \%$ of the studies $(n=23)$ having been published during or after 2010. The majority of the studies were qualitative $(n=17$, $55 \%)$, followed by quantitative $(n=11,35 \%)$, and literature reviews $(n=3,10 \%)$. The mean age of the participants was less than 35 years old in 28 of the studies included. The participants in the remaining three studies had a mean age between 35 to 65 years old and were included because data could be extracted specifically to participants aged 35 and younger. Studies were most often completed in the US $(n=10)$, Canada $(n=5)$, Australia $(n=4)$ and the Netherlands $(n=3)$. Single studies from Brazil, China, Namibia, New Zealand, South Africa, Sweden and the UK were also included. Two studies had representation from more than one country.

Intellectual or developmental disability $(n=9)$, sensory impairments including vision and hearing loss $(n=7)$ and cerebral palsy (CP) $(n=6)$, were the brain-based disabilities most frequently examined in the included studies. Other brain-based disabilities examined include spinal cord injury (SCI) or other spinal conditions, muscular dystrophy (MD), learning disability (LD) or dyslexia, epilepsy, spina bifida (SB), autism spectrum disorder (ASD), multiple sclerosis (MS), attention-deficit hyperactivity disorder (ADHD), traumatic brain injury (TBI) and other neurological conditions. Selected studies 
included perspectives of young adults $(n=28)$, parent or caregivers $(n=5)$, employers $(n=4)$, health care providers or unspecified support persons $(n=2)$ and vocational support specialists $(n=3)$. Six of the articles reviewed included multiple stakeholder perspectives.

Many of the qualitative studies ( $n=17$ ) utilized interviews or focus groups as their primary means of collecting data from participations. Five of the 31 included studies utilizing outcome measures to collect data/information about work participation. These measures included the Assessments of Life Habits [24], the Work Experience Survey [25], the Career Mastery Inventory [25], the Beach Centre Family Quality of Life Scale [26], the Developmental Behaviour Checklist adult version [26], the Index of Social Competence [26], the Stages of Change work Participation Scale [27], and the Vocational Integration Inventory [28]. Only one standardized measure addressed all aspects of the environment; the Measure of the Quality of the Environment [24], while the others focused on a single-domain measure of the environment such as the Family Support questionnaire [26]. Other studies identified environmental factors in the workplace by either relying on data from national surveys or by using their own questionnaires/surveys without any psychometric tests to validate them [27-32].

The majority of the included studies (71\%) examined more than one facet of the ICF environmental domains with regards to work participation. The domain of Services, systems and policies $(n=24$, $77 \%)$ was most frequently examined in the literature followed by the Support and relationships $(n=21$, $68 \%)$, Products \& technology /Natural environment and human-made changes to environment $(n=17$, $55 \%$ ), and Attitudes ( $n=15,48 \%$ ) (see Figure 2).

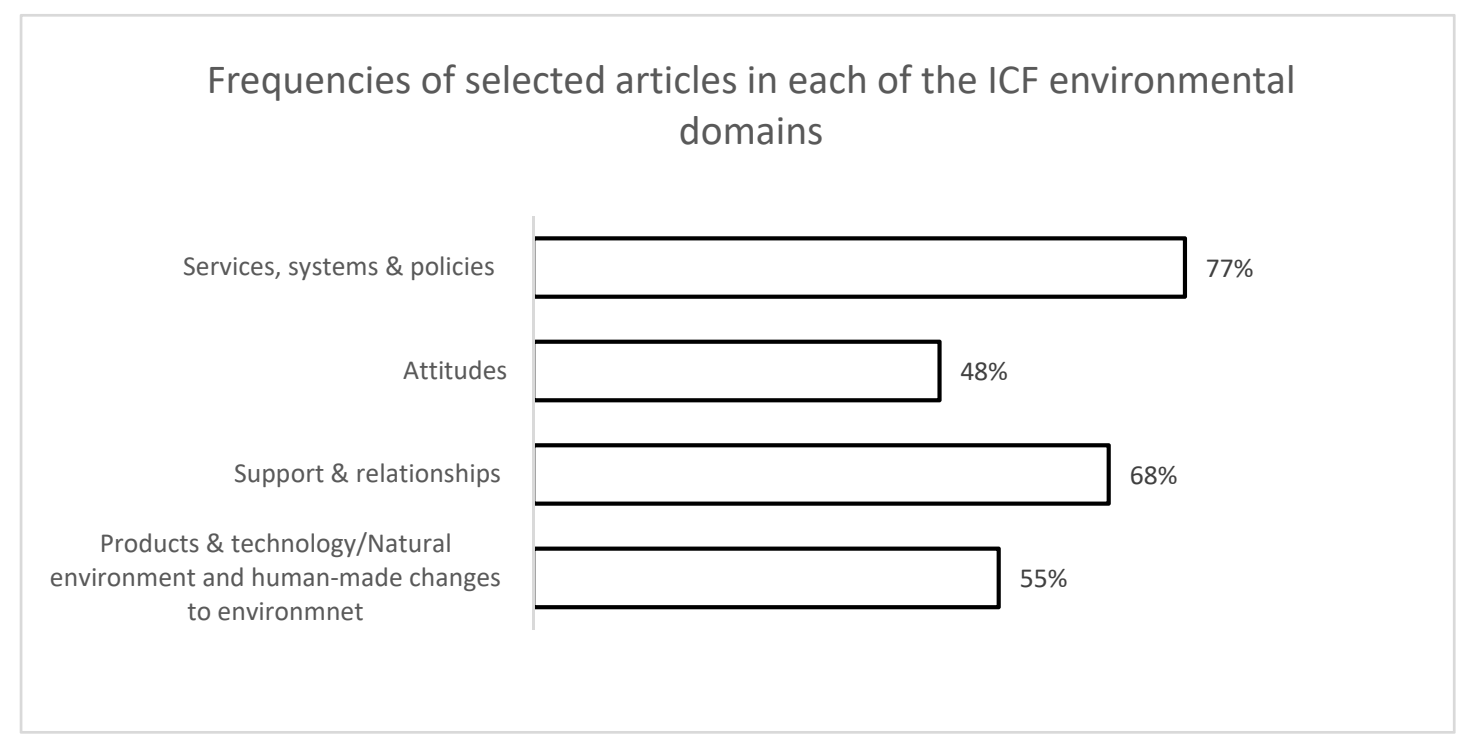

Figure 2. Frequencies of selected articles in each of the International Classification of Functioning, Disability and Health (ICF) environmental domains.

\subsection{Main Findings}

\subsubsection{Products and Technology/Natural Environment and Human-Made Changes to Environment}

Among the reviewed articles, 17 (55\%) addressed the role of the physical and sensory environments on young adults' participation in the workplace. Identified barriers included the lack of physical accessibility and assistive technology, inflexible and unreliable transportation systems and in some cases, inadequate lighting and temperature of the work setting [30,33-35]. To illustrate, participants with osteogenesis imperfecta, spina bifida or other impairments caused by accidents in the US and in Norway, required workplace accommodations related to the built environment (e.g., accessible paths and bathrooms, ramps, railings, door handles), assistive technology (e.g., voice recognition software), and ergonomic office tools (e.g., a specialized mouse or an adjustable desk) to promote their performance and engagement in the workplace [33]. The sensory environment, including lighting and 
temperature, also influenced the employee's ability to effectively perform his/her tasks. For example, the brightness of the environment often caused headaches or impeded computer work due to excessive reflection of light on the desktop among employees with TBI [25].

Studies also discussed the consequences associated with physical environment barriers and the perceived cost of adapting the environment. Failure to provide appropriate accommodations resulted in embarrassing situations and prevented persons with a disability to perform their responsibilities to the best of their abilities [30]. The cost of providing accommodations and adapting the physical environment was reported as a barrier to acquiring a job [29]. In fact, young adults reported that requiring fewer physical adaptations in the workplace increased their chance of acquiring a job [32].

Many studies found that access to adequate transportation is imperative for acquiring and retaining employment [34-36]. Long distance transportation was depicted as a hindrance to working [29]. In fact, transportation was a significant predictor of paid employment amongst young adults with mobility, hearing, vision, communication and/or cognitive impairments [12,37]. Flexible and timely transportation was found to support employment of those with physical disabilities [33]. Additionally, access to a vehicle as either a passenger or driver increased the likelihood of acquiring employment among young adults with various types of disabilities [37]. Lindsay [37] also reported the impact of geographical location on employment rate for individuals in their early years of transitioning who use mobility devices: those living in urban areas were more likely to find a job compared to those living in rural areas. This finding could be explained by other environmental barriers common in these geographical areas, such as a poor economy, scarcity of jobs and lack of services in certain areas that disadvantage people with disabilities [24,26,37].

Environmental supports were also identified; an accessible work environment in which accommodations were made to meet the employee's needs, optimized performance and facilitated engagement in the workplace $[30,38]$. Many employees reported working from home $[25,33,38]$ and using assistive technology such as Dictaphones, dual monitors, assistive devices for communication and computerized phones and alarms, positively impacted work satisfaction and work maintenance [33,39-41].

\subsubsection{Support and Relationships}

Twenty-one articles (68\%) fell under this category. The main barriers involved young adults' lack of social support or their perception of low support from parents [38]. However, interestingly, those with autism [42] and spina bifida [34] who had high parental support or overprotective parents were even less likely to be employed. Hence, family members, especially parents, played a significant role in finding and maintaining employment $[31,43]$. The main barriers to employment opportunities for those with autism [44] and intellectual disabilities [26,45] included lack of parental support, time, awareness and knowledge of abilities, parental fatigue and unwillingness to facilitate job search. Family involvement facilitated finding and maintaining employment by guiding career planning and adequate job search, providing support at the workplace, and in some cases, assisting with transportation $[27,44,45]$. Additionally, having parents with high work-related expectations, who advocated supported employment and provided emotional support, increased the likelihood of being employed and meeting the demands of the job on a daily basis [45] among those with learning disabilities [30] and various types of disabilities [46].

Additional social support from peers and co-workers also emerged as a main facilitator for employment. Sung and Connor [27] demonstrated that in the presence of other important factors (e.g., self-efficacy), $22.5 \%$ of the variation in employment among transition-aged individuals with epilepsy was explained by the support they received from parents, friends and professionals. This involved helping them develop specific independence skills required in the workplace [27,34]. Peer support, especially from those already employed, was another facilitator that encouraged and motivated individuals with brain-based disabilities to look for employment [47]. In addition, engagement in work was facilitated in inclusive workplaces in which interaction between co-workers was encouraged [32,44]. In fact, some of the strategies that service agencies used to support 
the integration of young adults with disabilities included building relationships and prompting co-workers and supervisors to actively invite employees to socialize during breaks, lunches and while performing the job [44]. Furthermore, a systematic review by De Beer et al. [38] indicated that assistance from colleagues was among the supports that facilitated employment for young adults with developmental dyslexia. To illustrate, having colleagues proofread their work predicted better employment outcomes $[30,35]$, and positive interactions in the workplace led to their career advancement [46]. Participating in work-related social activities such as going to staff functions, eating lunch with other employees and developing interpersonal relationships with co-workers that expanded beyond the workplace, also increased the likelihood of employees with intellectual disabilities to keep their job $[28,48]$.

Management styles within the organization played a role in work experiences of this transitioning population. Approachable managers who created inclusive and fair work environments, as well as those who built relationships and created a strong sense of teamwork, increased engagement in the workplace for those with developmental disabilities [28]. Similarly, managers who had direct contact with their employees, closely collaborated with employment service providers and allowed for work trials rather than interviews, facilitated the employment of young adults with ASD [49]. Moreover, young adults with disabilities were happier in workplaces where they were treated equally [33] and felt that their skills and opinions were valued by the managers [49].

\subsubsection{Attitudes}

This environmental factor was addressed in $15(48 \%)$ studies in which attitudes of others towards persons with a brain-based disability was mainly seen as a barrier to their employment and participation in the workplace. Young adults with a disability often experienced prejudice and stigma from their employers and co-workers in the workplace. For example, they generally got hired for less skilled occupations as their employers did not believe in their abilities [30,32]. Lindsay et al. [47], illustrated the misconceptions from employers regarding the functional abilities of people with physical disabilities and the negative impact of societal attitudes on their employment. Additionally, many young adults with brain-based disabilities hesitated to disclose their diagnosis (e.g., learning disabilities) to their employer due to fear of discrimination [30]. In their systematic review, De Beer et al. [38] revealed that the reaction of co-workers to this transition-aged population was mostly negative. This negative attitude which usually stems from a lack of knowledge, led to negative experiences for the employee when seeking out a job, i.e., increased stress during the interview, as well as in retaining a position $[34,50,51]$. In other words, this prejudice created obstacles in young adults' abilities to acquire and enter the labor market or to advance in their careers [30,52]. For example, stereotypes associated with this population such as their inability to work, their need for costly accommodations or their unwillingness to be active members, hindered persons with a disability to exhibit and exercise their skills in the workplace. This was evident in various types of brain-based disabilities, including physical, intellectual and sensory related impairments [39,52,53]. In one study, it was found that this negative perception and discrimination led to higher rates of unlawful discharge of young adults with epilepsy as compared to their colleagues [51]. Overall, approachable employers with positive attitudes and sensitivity to the needs of the employee created positive work experiences and led to better employment satisfaction $[30,49,50]$.

\subsubsection{Services, Systems and Policies}

The majority of the studies $(n=24,77 \%$ ) focused on the impact of services, systems and policies on both acquiring/finding a job and maintaining participation in the workplace. Internal factors, those within the organization/workplace, and external factors, those outside the organization/workplace, were identified.

Internal organization-based barriers and facilitators. Barriers within the organization included complex procedures to obtain and implement accommodations. To illustrate, the organization's lack of flexibility 
in allocating resources and its lengthy bureaucratic processes were reported as barriers for obtaining accommodations $[25,33,44,52]$. The delay in providing necessary services or the lack of support systems in the workplace (e.g., clear guidelines) also created barriers to maintaining employment [33,52]. Unpreparedness of companies and organizations and the lack of awareness of existing policies and resources, as well as limited knowledge on how to implement those policies in their workplace, impeded the successful engagement in employment [53]. Specifically, knowledge on how to select and hire a person with disability, what type of accommodations to provide, and how to handle different situations was limited $[30,32,34,47]$. This issue was evident in organizations where accommodations were made based on the employers" "recognition" and their "willingness/readiness" to provide services, or in organizations that determined the employee's accommodation needs based on a strictly medical-oriented approach [33]. In such cases, the medical diagnosis rather than the employee's level of function or needs informed the decision of providing accommodations. Limited funding to support awareness of employers and colleagues about disability [49] and insufficient recognition of various types of certificates or diplomas [40] further accentuated this barrier. Additionally, workplaces in which employees were not given constructive feedback, their abilities, skills and contribution were not recognized nor valued, and where they were not involved in the decision-making process, reduced opportunities to advance their careers $[25,51,52]$.

Characteristics of the organization in terms of employment expectations (e.g., task demands, schedules) and availability of support services were reported as facilitators. Work settings that showed flexibility, especially in determining schedules and adapting job demands to the abilities of their employees, facilitated participation $[38,44,54]$. Flexible organizations that provided adequate accommodations (e.g., allocated more time, allowed work from home, provided breaks as needed, ensured consistent work routine) in a timely manner contributed to the employment of this population $[25,33,50]$. Those that provided individual-based support to their employees in work (e.g., communicated a change in medication to the employer; broke down or simplified tasks, set work goals, provided personal help to go to the bathroom) and non-work-related areas (e.g., helped adjusting to moving to a new residence) as well as guiding their employees on company policies, protocols and culture (e.g., taking time off for medical reasons), facilitated job sustainability $[36,39,49,54]$. Offering supervision and appropriate training on work demands and the social cues within the workplace, was another perceived facilitator [28,48-50,54]. The provision of ongoing support combined with clear job descriptions and expectations helped young adults maintain their jobs and progress in their careers [49]. Finally, organizations that promoted disability awareness and provided training for staff increased the likelihood of creating an engaging work environment for this population $[25,49,50]$.

External barriers and facilitators. Factors external to the organization/workplace were also observed and involved both aspects of services and policies. In terms of access to employment supports and services, employees with disability expressed the need for more services to find employment as well as support in the workplace to maintain it. For example, young adults reported that employment services that helped with job applications, but did not assist in job searching that fitted their abilities, made finding employment difficult [40]. Additionally, scarcity of accessible employment and lack of professional support further limited their ability to enter the workforce $[24,34,35,47,53]$. Access to adult service agencies, disability employment services, job coaches, social workers and school staff, that provided training to employers and supported the employee on the job, facilitated transitioning to the workforce $[44,48]$.

Policies addressing laws and regulations external to the organization, to support inclusion and workplace participation, also had an impact on successful employment as evident in a few studies. The availability of policies and their implementation in workplaces were mainly examined. Parents of young adults with developmental disabilities were concerned about the lack of macro-level policies supporting employment [26]. A study done in Namibia [43] revealed that inclusion policies for young adults with visual impairments were not effective in the workplace and were not implemented. Another study completed in both the United States and Norway highlighted that although some policies such 
as the Americans with Disability Act (ADA) recognized the rights of people with disability in the workplace and promoted "reasonable accommodations," they were unclear about the extent and the range of assistance that should be provided. This resulted in the provision of inadequate assistance to the employee, impacting their ability to perform their jobs [33]. Different types of government programs had varying impacts on the access to employment of this population. For example, government wage subsidies were found to facilitate employment in some countries such as Sweden [33,36]. On the other hand, sheltered employment programs restricted the ability of the individual to acquire open and competitive employment in Australia [26]. Finally, young adults also expressed that the removal or reduction of government-based income benefits after acquiring well-paid employment prevented them from reaching their full potential at work $[33,40,51]$.

\subsubsection{Other Contextual Factors}

Contextual factors that did not fit any of the ICF environmental domains yet contributed to the employment of young adults with brain-based disabilities emerged and are grouped under personal factors. Examples include financial advantages, educational opportunities, and opportunities to participate in extracurricular activities and in the community (e.g., volunteering) [30,47]. Studies found that lack of previous work experience and lower levels of education contributed to fewer employment opportunities [31]. Similarly, Lindstrom et al. [46] and Lindsay et al. [34] concluded that higher levels of education led to broader qualified jobs with a higher salary within this population. Among the facilitators, Lindsay [37] showed that lower household income and fewer household members were associated with increased probability of having paid employment among individuals with cognitive or communication impairments. Young adults who benefitted from disability services and supports, and those who participated in the Co-op and internship programs offered through their high school and post-secondary schools were also found to have better employment opportunities $[34,46]$.

\section{Discussion}

This scoping review revealed that all aspects of the environment as described by the ICF have an impact on workplace participation as a barrier and/or as a facilitator, expanding previous research conducted among those with ID [14] and ASD [13], to a broader range of brain-based disabilities. Specifically, a large body of evidence (77\% of the studies) focused on the impact of services, systems and policies on both acquiring and maintaining a job. An emphasis was placed on the role of the organizations in creating an inclusive work environment, providing training for and promoting disability awareness of managers and staff, as well as embracing positive attitudes. As such, findings draw attention towards the developing of interventions that reduce the environmental barriers at the organizational level, identified in this review.

None of the studies examined the effectiveness of existing policies that specifically promote employment and workplace participation at the macro-level (i.e., provincial and national policies in the larger societal context). The few studies that mentioned "policies", described the lack of awareness and at times, willingness to implement existing policies in the workplace. The same pattern was seen among older adults with disabilities who face work participation challenges due to either inadequate implementation of policies and regulation or the lack of it all together to support their work participation $[55,56]$. This further emphasizes the importance of implementing policies at early stages since that is when young people enter the work force. Furthermore, not only are there very few policies to promote the employment of this population but there are no clear guidelines and procedures on how to implement and reinforce them in the workplace. Future research can address this issue by developing adequate policies, proposing and testing effective ways to disseminate information on policies to stakeholders (e.g., managers, supervisors, employers and employees with and without disabilities) as well as finding adequate ways to implement them. This can be achieved by providing educational programs, as well as having clear procedures and processes in place to implement them. 
Studies also demonstrated the positive impact of social support while shedding light on the detrimental effect of negative attitudes on workplace inclusion of this population. This finding supports the need for effective interventions by service providers and policymakers to improve attitudes in the work environment. This can be done through educational initiatives, increasing others' knowledge about disability and inclusion as well as providing information on how to make successful accommodations in the workplace. Furthermore, findings highlight the use of assistive technology in enhancing work participation by facilitating the completion of certain work tasks and performance of responsibilities. With rapidly developing technological solutions, putting in place technology-based accommodations (applications, software) has become readily available [41], making the implementation of such accommodations more practical.

Several knowledge gaps were identified. Although the literature described a range of environmental barriers that impacted workplace participation, there is still little that is known on effective strategies to overcome these environmental barriers. Indeed, only seven studies (out of 31) described strategies used to facilitate work participation, without evaluating their impact. The available examples of actions that organizations can take, focused mainly on improving physical accommodations (e.g., providing assistive technology, giving extra time to complete tasks, creating an accessible environment), with little evidence on strategies to remove other important barriers like attitudinal (e.g., discrimination, pre-conceived ideas about disability), organizational (e.g., rigid task demands and schedules), and institutional (e.g., lack of training and support). In addition, the majority of the included studies were qualitative in nature. This can be complemented by quantitative studies using advanced statistical methods to systematically evaluate the environment and the workplace participation. Furthermore, most of the studies employed a cross-sectional design, with only two longitudinal studies, suggesting that available evidence is limited in claiming causal relationship between the environment and participation. Notably, while our approach to synthesize evidence according to the domains of the ICF appeared overall appropriate, only five studies (out of the 31) explicitly used the ICF as a guide. Finally, very few of the quantitative studies administered standardized, comprehensive and psychometrically sound measures to evaluate environmental factors that affect participation in the workplace.

The knowledge synthesized may guide employment-related service providers to identify specific environmental characteristics that are important, need to be evaluated, and are potential areas for intervention. Findings demonstrate that there is a strong promise in shifting focus toward the environment, rather than solely focusing on the skills of transition-aged individuals with brain- based disabilities. Interventions, programs and policies can target support and services at the institutional level (within a broader structural context such as social systems/community agencies) and organizational level (within the immediate workplace environment) as these factors were commonly identified as barriers/supports. This information can be used to develop or strengthen environment-based interventions, such as the Pathways and Resources for Engagement and Participation (PREP), proven effective in improving community participation among transition-aged young people by only changing aspects of their environment [57]. Policymakers can also draw on this knowledge to develop clear and specific guidelines to implement and reinforce policies in the work environment. Transition programs and services based in the community can also benefit from this knowledge by developing programs that address specific environmental barriers, faced by young individuals, and foster their inclusion in open and competitive employment.

A limitation of this study is that grey literature and articles not published in English were excluded, which may have resulted in important information being missed. Additionally, given that the aim of this review was to synthesize literature related to the impact of the environment on open and competitive employment, studies focusing on participation in sheltered employment were excluded. Thus, it is possible that information relevant to the environmental impact on employment participation was omitted. Typical to scoping reviews [21], no quality assessment of the included studies was conducted due to the large number of research designs and variety in methodological approaches of the included studies. Given that this topic is a newly studied area, the intent of this review was to 
synthesize all information available without parameters related to study quality. Thereby, no firm conclusions can be made about the effectiveness or the magnitude of the effect of the environment on work participation among young adults with brain-based disabilities.

\section{Conclusions}

Findings highlight the role of the environment in facilitating and/or hindering employment. Particularly, environmental factors at the organizational level and at the institutional level appear to be critical in fostering workplace participation in this population.

Author Contributions: Conceptualization: S.S. and D.A.; methodology: S.S., D.A. and B.D.R.; validation: D.A., S.A. and B.D.R.; formal analysis, S.S. and M.R.; investigation, S.S. and M.R.; resources, D.A.; data curation, S.S. and M.R.; writing—original draft preparation, S.S. and M.R.; writing—review and editing, S.S., M.R., S.A., B.D.R. and D.A.; visualization: S.S. and M.R.; supervision: D.A.; project administration, S.S. All authors have read and agreed to the published version of the manuscript.

Funding: This research received no external funding.

Acknowledgments: We thank Noah Margolese, Zoe Lavallee and Ai-Vi Nguyen for their contribution to this project.

Conflicts of Interest: The authors declare no conflict of interest.

\section{References}

1. World Health Organization. International Classification of Functioning, Disability and Health; ICF: Geneva, Switzerland, 2001.

2. Chang, F.-H.; Coster, W.J. Conceptualizing the Construct of Participation in Adults with Disabilities. Arch. Phys. Med. Rehabil. 2014, 95, 1791-1798. [CrossRef] [PubMed]

3. Van Gorp, M.; Van Wely, L.; Dallmeijer, A.J.; de Groot, V.; Ketelaar, M.; Roebroeck, M.E. Long-Term Course of Difficulty in Participation of Individuals with Cerebral Palsy Aged 16 to 34 Years: A Prospective Cohort Study. Dev. Med. Child Neurol. 2019, 61, 194-203. [CrossRef] [PubMed]

4. Frey, B.S.; Stutzer, A. Happiness and Economics: How the Economy and Institutions Affect Human Well-Being; Princeton University Press: Princeton, NJ, USA, 2002.

5. Luecking, L.G.; Mooney, M. Tapping Employment Opportunities for Youth with Disabilities by Engaging Effectively with Employers. Res. Pract. Br. 2002, 1,1-5.

6. Statistics Canada. A Profile of Persons with Disabilities Among Canadians Aged 15 Years or Older. Available online: http://www.statcan.gc.ca/pub/89-654-x/89-654-x2015001-eng.htm\#r5 (accessed on 27 March 2020).

7. World Health Organization. World Report on Disability; WHO: Geneva, Switzerland, 2011.

8. Palmer, M. Disability and Poverty: A Conceptual Review. J. Disabil. Policy Stud. 2011, 21, 210-218. [CrossRef]

9. Wehman, P.; Taylor, J.; Brooke, V.; Avellone, L.; Whittenburg, H.; Ham, W.; Brooke, A.M.; Carr, S. Toward Competitive Employment for Persons with Intellectual and Developmental Disabilities: What Progress Have We Made and Where Do We Need to Go. Res. Pract. Pers. Sev. Disabil. 2018, 43, 131-144. [CrossRef]

10. Anaby, D.; Law, M.; Coster, W.; Bedell, G.; Khetani, M.; Avery, L.; Teplicky, R. The Mediating Role of the Environment in Explaining Participation of Children and Youth with and without Disabilities across Home, School, and Community. Arch. Phys. Med. Rehabil. 2014, 95, 908-917. [CrossRef]

11. Unger, D.D. Employers' Attitudes toward Persons with Disabilities in the Workforce: Myths or Realities? Focus Autism Dev. Disabl. 2002, 17, 2-10. [CrossRef]

12. Lindsay, S. Discrimination and Other Barriers to Employment for Teens and Young Adults with Disabilities. Disabil. Rehabil. 2011, 33, 1340-1350. [CrossRef]

13. Khalifa, G.; Sharif, Z.; Sultan, M.; Di Rezze, B. Workplace Accommodations for Adults with Autism Spectrum Disorder: A Scoping Review. Disabil. Rehabil. 2019, 1-16. [CrossRef]

14. Ellenkamp, J.J.H.; Brouwers, E.P.M.; Embregts, P.J.C.M.; Joosen, M.C.W.; van Weeghel, J. Work Environment-Related Factors in Obtaining and Maintaining Work in a Competitive Employment Setting for Employees with Intellectual Disabilities: A Systematic Review. J. Occup. Rehabil. 2016, 26, 56-69. [CrossRef] 
15. Wolf-Branigin, M.; Schuyler, V.; White, P. Improving Quality of Life and Career Attitudes of Youth With Disabilities: Experiences From the Adolescent Employment Readiness Center. Res. Soc. Work Pract. 2007, 17, 324-333. [CrossRef]

16. Arksey, H.; O'Malley, L. Scoping Studies: Towards a Methodological Framework. Int. J. Soc. Res. Methodol. 2005, 8, 19-32. [CrossRef]

17. Levac, D.; Colquhoun, H.; O’Brien, K.K. Scoping Studies: Advancing the Methodology. Implement. Sci. 2010, 5, 1-9. [CrossRef] [PubMed]

18. Di Rezze, B.; Nguyen, T.; Mulvale, G.; Barr, N.; Longo, C.; Randall, G. A Scoping Review of Evaluated Interventions Addressing Developmental Transitions for Youth with Mental Health Disorders. Child Care Health Dev. 2016, 42, 176-187. [CrossRef] [PubMed]

19. (UNICEF). Age-Related Barriers to Service Access and the Realisation of Rights for Children, Adolescents and Youth. Available online: https://agemattersnow.org/downloads/YPL_Age_Matters_Final_Report_Oct2016. pdf (accessed on 27 March 2020).

20. World Health Organization. Adolescence: A Period Needing Special Attention. Available online: http://apps.who.int/adolescent/second-decade/section2/page1/recognizing-adolescence.html (accessed on 27 March 2020).

21. Pham, M.; Rajić, A.; Greig, J.; Sargeant, J.; Papadopoulos, A.; McEwen, S. A Scoping Review of Scoping Reviews: Advancing the Approach and Enhancing the Consistency. Res. Synth. Methods 2014, 5, 371-385. [CrossRef] [PubMed]

22. Elo, S.; Kyngas, H. The Qualitative Content Analysis Process. J. Adv. Nurs. 2008, 62, 107-115. [CrossRef]

23. Kastner, M.; Tricco, A.C.; Soobiah, C.; Lillie, E.; Perrier, L.; Horsley, T.; Welch, V.; Cogo, E.; Antony, J.; Straus, S.E. What Is the Most Appropriate Knowledge Synthesis Method to Conduct a Review? Protocol for a Scoping Review. BMC Med. Res. Methodol. 2012, 12, 114. [CrossRef]

24. Foley, K.-R.; Girdler, S.; Bourke, J.; Jacoby, P.; Llewellyn, G.; Einfeld, S.; Tonge, B.; Parmenter, T.R.; Leonard, H. Influence of the Environment on Participation in Social Roles for Young Adults with down Syndrome. PLoS ONE 2014, 9, 1-11. [CrossRef]

25. Roessler, R.T.; Rumrill, P.D.J.; Rumrill, S.P.; Minton, D.L.; Hendricks, D.J.; Sampson, E.; Stauffer, C.; Scherer, M.J.; Nardone, A.; Leopold, A.; et al. Qualitative Case Studies of Professional-Level Workers with Traumatic Brain Injuries: A Contextual Approach to Job Accommodation and Retention. Work 2017, 58, 3-14. [CrossRef]

26. Foley, K.-R.; Girdler, S.; Downs, J.; Jacoby, P.; Bourke, J.; Lennox, N.; Einfeld, S.; Llewellyn, G.; Parmenter, T.R.; Leonard, H. Relationship between Family Quality of Life and Day Occupations of Young People with Down Syndrome. Soc. Psychiatry Psychiatr. Epidemiol. 2014, 49, 1455-1465. [CrossRef]

27. Sung, C.; Connor, A. Social-Cognitive Predictors of Vocational Outcomes in Transition Youth with Epilepsy: Application of Social Cognitive Career Theory. Rehabil. Psychol. 2017, 62, 276-289. [CrossRef] [PubMed]

28. Butterworth, J.; Hagner, D.; Helm, D.T.; Whelley, T.A. Workplace Culture, Social Interactions, and Supports for Transition-Age Young Adults. Ment. Retard. 2000, 38, 342-353. [CrossRef]

29. Barf, H.A.; Post, M.W.M.; Verhoef, M.; Jennekens-Schinkel, A.; Gooskens, R.H.J.M.; Prevo, A.J.H. Restrictions in Social Participation of Young Adults with Spina Bifida. Disabil. Rehabil. 2009, 31, 921-927. [CrossRef]

30. Greenbaum, B.; Granham, S.; Scales, W. Occupational and Social Status after College. J. Learn. Disabil. 1996, 29, 167-173. [CrossRef] [PubMed]

31. Honey, A.; Kariuki, M.; Emerson, E.; Llewellyn, G. Employment Status Transitions among Young Adults, with and without Disability. Aust. J. Soc. Issues 2014, 49, 151-170. [CrossRef]

32. Toldrá, R.C.; Santosb, M.C. People with Disabilities in the Labor Market: Facilitators and Barriers. Work 2013, 45, 553-563. [CrossRef] [PubMed]

33. Solstad, V.J.; Schreuer, N. Policy in Action: Stories on the Workplace Accommodation Process. J. Disabil. Policy Stud. 2011, 22, 95-105. [CrossRef]

34. Lindsay, S.; McPherson, A.C.; Maxwell, J. Perspectives of School-Work Transitions among Youth with Spina Bifida, Their Parents and Health Care Providers. Disabil. Rehabil. 2017, 39, 641-652. [CrossRef]

35. Sherer, M.; Davis, L.C.; Sander, A.M.; Caroselli, J.S.; Clark, A.N.; Pastorek, N.J. Prognostic Importance of Self-Reported Traits/Problems/Strengths and Environmental Barriers/Facilitators for Predicting Participation Outcomes in Persons with Traumatic Brain Injury: A Systematic Review. Arch. Phys. Med. Rehabil. 2014, 95, 1162-1173. [CrossRef] 
36. Törnbom, M.; Jonsson, U.; Sunnerhagen, K.S. Work Participation among Middle-Aged Persons with Cerebral Palsy or Spina Bifida-a Longitudinal Study. Disabil. Health J. 2014, 7, 251-255. [CrossRef]

37. Lindsay, S. Employment Status and Work Characteristics among Adolescents with Disabilities. Disabil. Rehabil. 2011, 33, 843-854. [CrossRef] [PubMed]

38. De Beer, J.; Engels, J.; Heerkens, Y.; van der Klink, J. Factors Influencing Work Participation of Adults with Developmental Dyslexia: A Systematic Review. BMC Public Health 2014, 14, 1-22. [CrossRef] [PubMed]

39. Ripat, J.D.; Woodgate, R.L. The Importance of Assistive Technology in the Productivity Pursuits of Young Adults with Disabilities. Work 2017, 57, 455-468. [CrossRef] [PubMed]

40. Darrah, J.; Magill-Evans, J.; Galambos, N.L. Community Services for Young Adults with Motor Disabilities-A Paradox. Disabil. Rehabil. 2010, 32, 223-229. [CrossRef]

41. Morash-Macneil, V.; Johnson, F.; Ryan, J.B. A Systematic Review of Assistive Technology for Individuals with Intellectual Disability in the Workplace. J. Spec. Educ. Technol. 2018, 33, 15-26. [CrossRef]

42. Holwerda, A.; van der Klink, J.J.L.; de Boer, M.R.; Groothoff, J.W.; Brouwer, S. Predictors of Sustainable Work Participation of Young Adults with Developmental Disorders. Res. Dev. Disabil. 2013, 34, 2753-2763. [CrossRef]

43. Tobias, E.I.; Mukhopadhyay, S. Disability and Social Exclusion: Experiences of Individuals with Visual Impairments in the Oshikoto and Oshana Regions of Namibia. Psychol. Dev. Soc. J. 2017, 29, 22-43. [CrossRef]

44. Hagner, D.; Butterworth, J.; Keith, G. Strategies and Barriers in Facilitating Natural Supports for Employment of Adults with Severe Disabilities. J. Assoc. Pers. Sev. Handicap. 1995, 20, 110-120. [CrossRef]

45. Petner-Arrey, J.; Howell-Moneta, A.; Lysaght, R. Facilitating Employment Opportunities for Adults with Intellectual and Developmental Disability through Parents and Social Networks. Disabil. Rehabil. 2016, 38, 789-795. [CrossRef]

46. Lindstrom, L.; Doren, B.; Miesch, J. Waging a Living: Career Development and Long-Term Employment Outcomes for Young Adults with Disabilities. Except Child. 2011, 77, 423-434. [CrossRef]

47. Lindsay, S.; McDougall, C.; Menna-Dack, D.; Sanford, R.; Adams, T. An Ecological Approach to Understanding Barriers to Employment for Youth with Disabilities Compared to Their Typically Developing Peers: Views of Youth, Employers, and Job Counselors. Disabil. Rehabil. 2015, 37, 701-711. [CrossRef] [PubMed]

48. Reid, P.M.; Bray, A. Paid Work and Intellectual Disability. J. Intellect. Dev. Disabil. 1997, 22, 87-96. [CrossRef]

49. Scott, M.; Falkmer, M.; Girdler, S.; Falkmer, T. Viewpoints on Factors for Successful Employment for Adults with Autism Spectrum Disorder. PLoS ONE 2015, 10, 1-15.

50. Li, E.P.Y. Self-Perceived Equal Opportunities for People with Intellectual Disability. Int. J. Rehabil. Res. 2004, 27, 241-245. [CrossRef]

51. Roessler, R.T.; Hawley, C.E.; McMahon, B.T. Employment Discrimination Experiences of Youth with Epilepsy: A Comparative Analysis. J. Vocat. Rehabil. 2012, 36, 149-158. [CrossRef]

52. Wilson-Kovacs, D.; Ryan, M.K.; Haslam, S.A.; Rabinovich, A. 'Just Because You Can Get a Wheelchair in the Building Doesn't Necessarily Mean That You Can Still Participate': Barriers to the Career Advancement of Disabled Professionals. Disabil. Soc. 2008, 23, 705-717. [CrossRef]

53. Lieketseng, N.; Lorenzo, T. Enhancing the Public Sector's Capacity for Inclusive Economic Participation of Disabled Youth in Rural Communities. Afr. J. Disabil. 2016, 5, 1-9.

54. Hagner, D.; Cooney, B.F. I Do That for Everybody: Supervising Employees with Autism. Focus Autism Dev. Disabl. 2005, 20, 91-97. [CrossRef]

55. Prodinger, B.; Weise, A.; Shaw, L.; Stamm, T. A Delphi Study on Environmental Factors That Impact Work and Social Life Participation of Individuals with Multiple Sclerosis in Austria and Switzerland. Disabil. Rehabil. 2010, 32, 183-195. [CrossRef]

56. Coelho, C.M.; Sampaio, R.F.; Luz, M.T.; Mancini, M.C. Work Reality Perceived by Individuals with Impairments: A Biopsychosocial Experience. Work 2013, 45, 537-551. [CrossRef]

57. Anaby, D.; Law, M.; Feldman, D.; Majnemer, A.; Avery, L. The effectiveness of the Pathways and Resources for Engagement and Participation (PREP) intervention: Improving participation of adolescents with physical disabilities. Dev. Med. Child Neurol. 2018, 60, 513-519. [CrossRef] [PubMed]

(C) 2020 by the authors. Licensee MDPI, Basel, Switzerland. This article is an open access article distributed under the terms and conditions of the Creative Commons Attribution (CC BY) license (http://creativecommons.org/licenses/by/4.0/). 